\title{
Where to find 1.5 million yr old ice for the IPICS "Oldest-Ice" ice core
}

\author{
H. Fischer ${ }^{1}$, J. Severinghaus ${ }^{2}$, E. Brook ${ }^{3}$, E. Wolff ${ }^{4, *}$, M. Albert ${ }^{5}$, O. Alemany ${ }^{6}$, R. Arthern ${ }^{4}$, C. Bentley ${ }^{7}$, \\ D. Blankenship ${ }^{8}$, J. Chappellaz ${ }^{6}$, T. Creyts ${ }^{9}$, D. Dahl-Jensen ${ }^{10}$, M. Dinn ${ }^{4}$, M. Frezzotti ${ }^{11}$, S. Fujita ${ }^{12}$, H. Gallee ${ }^{6}$, \\ R. Hindmarsh ${ }^{4}$, D. Hudspeth ${ }^{13}$, G. Jugie ${ }^{14}$, K. Kawamura ${ }^{12}$, V. Lipenkov ${ }^{15}$, H. Miller ${ }^{16}$, R. Mulvaney ${ }^{4}$, F. Parrenin ${ }^{6}$, \\ F. Pattyn ${ }^{17}$, C. Ritz $^{6}$, J. Schwander ${ }^{1}$, D. Steinhage ${ }^{16}$, T. van Ommen ${ }^{13}$, and F. Wilhelms ${ }^{16}$ \\ ${ }^{1}$ Climate and Environmental Physics, Physics Institute, University of Bern, Sidlerstrasse 5, 3012 Bern \\ \& Oeschger Centre for Climate Change Research, University of Bern, Switzerland \\ ${ }^{2}$ Scripps Institution of Oceanography, University of California, San Diego, California, USA \\ ${ }^{3}$ Department of Geosciences, Oregon State University, Corvallis, Oregon, USA \\ ${ }^{4}$ British Antarctic Survey, High Cross, Cambridge, UK \\ ${ }^{5}$ Thayer School of Engineering, Dartmouth University, Hanover, New Hampshire, USA \\ ${ }^{6}$ Laboratoire de Glaciologie et Géophysique de l'Environnement, UJF-Grenoble, CNRS, St Martin d'Hères, France \\ ${ }^{7}$ University of Wisconsin Madison, Madison, Wisconsin, USA \\ ${ }^{8}$ Institute for Geophysics, University of Texas at Austin, Austin, Texas, USA \\ ${ }^{9}$ Lamont Doherty Earth Observatory, Columbia University, Palisades, New York, USA \\ ${ }^{10}$ Centre for Ice and Climate, Niels Bohr Institute, University of Copenhagen, Copenhagen, Denmark \\ ${ }^{11}$ ENEA-CRE, Casaccia, Rome, Italy \\ ${ }^{12}$ National Institute of Polar Research, Tokyo, Japan \\ ${ }^{13}$ Australian Antarctic Division, Hobart, Tasmania, Australia \\ ${ }^{14}$ Institut Polaire Français Paul-Emile Victor, Plouzané, France \\ ${ }^{15}$ Arctic and Antarctic Research Institute, St. Petersburg, Russia \\ ${ }^{16}$ Alfred Wegener Institute for Polar and Marine Research, Bremerhaven, Germany \\ ${ }^{17}$ Laboratoire de Glaciologie, Université Libre de Bruxelles, Brussels, Belgium \\ *now at: Department of Earth Sciences, University of Cambridge, Cambridge, UK
}

Correspondence to: H. Fischer (hubertus.fischer@climate.unibe.ch.)

Received: 30 April 2013 - Published in Clim. Past Discuss.: 27 May 2013

Revised: 19 September 2013 - Accepted: 26 September 2013 - Published: 5 November 2013

\begin{abstract}
The recovery of a 1.5 million yr long ice core from Antarctica represents a keystone of our understanding of Quaternary climate, the progression of glaciation over this time period and the role of greenhouse gas cycles in this progression. Here we tackle the question of where such ice may still be found in the Antarctic ice sheet. We can show that such old ice is most likely to exist in the plateau area of the East Antarctic ice sheet (EAIS) without stratigraphic disturbance and should be able to be recovered after careful presite selection studies. Based on a simple ice and heat flow model and glaciological observations, we conclude that positions in the vicinity of major domes and saddle position
\end{abstract}

on the East Antarctic Plateau will most likely have such old ice in store and represent the best study areas for dedicated reconnaissance studies in the near future. In contrast to previous ice core drill site selections, however, we strongly suggest significantly reduced ice thickness to avoid bottom melting. For example for the geothermal heat flux and accumulation conditions at Dome $\mathrm{C}$, an ice thickness lower than but close to about $2500 \mathrm{~m}$ would be required to find 1.5 Myr old ice (i.e., more than $700 \mathrm{~m}$ less than at the current EPICA Dome $\mathrm{C}$ drill site). Within this constraint, the resolution of an Oldest-Ice record and the distance of such old ice to the bedrock should be maximized to avoid ice flow disturbances, 
for example, by finding locations with minimum geothermal heat flux. As the geothermal heat flux is largely unknown for the EAIS, this parameter has to be carefully determined beforehand. In addition, detailed bedrock topography and ice flow history has to be reconstructed for candidates of an Oldest-Ice ice coring site. Finally, we argue strongly for rapid access drilling before any full, deep ice coring activity commences to bring datable samples to the surface and to allow an age check of the oldest ice.

\section{Introduction}

The sequence of the last 8 glacial cycles documented in natural paleoclimate archives (EPICA community members, 2004; Lisiecki and Raymo, 2005; Wang et al., 2008; Wolff et al., 2006; Pahnke and Zahn, 2005; Elderfield et al., 2012) is characterized by irregular $100000 \mathrm{yr}$ cycles, whose association to Milankovitch cycles is still a matter of debate. Each cycle comprises either four to five $23 \mathrm{kyr}$ precession cycles (Raymo et al., 2006) with relatively gradual cooling and ice expansion phases and relatively short (about $10000 \mathrm{yr}$ ) deglaciations. Over this time both climate and greenhouse gases vary mainly in parallel (Loulergue et al., 2008; Petit et al., 1999; Lüthi et al., 2008). For the last glacial termination, ice core and other climate records suggest that $\mathrm{CO}_{2}$ is leading the climate change in the Northern Hemisphere (Shakun et al., 2012) but being in phase (Parrenin et al., 2013) or slightly lagging the warming in the Southern Ocean region (Pedro et al., 2012; Shakun et al., 2012). This documents the important contribution of atmospheric $\mathrm{CO}_{2}$ concentration to the occurrence of deglaciations, while the full switch from glacial to interglacial conditions also requires the albedo feedback imposed by the slowly receding continental ice coverage in the Northern Hemisphere.

In contrast, the time period between $1.5 \mathrm{Myr}$ and about 1.2 Myr ago is characterized by more regular cycles and a significantly higher frequency of glacial-interglacial changes with a Milankovitch-related obliquity periodicity of $41000 \mathrm{yr}$. Based on a stack of benthic $\delta^{18} \mathrm{O}$ foraminifera records (Lisiecki and Raymo, 2005) it is suggested that this change occurred in the time interval between $1.2 \mathrm{Myr}$ and $900000 \mathrm{yr}$ BP (before present, where present is defined as 1950), and this change has been termed the mid-Pleistocene transition (MPT). Only recently, Elderfield et al. (2012) suggested that the switch from this so called " $40 \mathrm{k}$ world" to a " $100 \mathrm{k}$ world" may have occurred quite rapidly before 900 kyr BP. An important question concerns the speed of the MPT and what drove this switch in cyclicity, in particular whether it is controlled by changes in atmospheric $\mathrm{CO}_{2}$ and other greenhouse gases. For example a recent ice sheetclimate model study suggests that glacial-interglacial transitions in the Laurentide ice sheet inherently occur with the most prominent periodicity of about $100 \mathrm{kyr}$ for a given $\mathrm{CO}_{2}$ concentration of 220 ppmv (Abe-Ouchi et al., 2013). Under these $\mathrm{CO}_{2}$ conditions, the Laurentide ice sheet has to grow for about $100000 \mathrm{yr}$ to reach a critical state, after which it may rapidly collapse in response to higher summer insolation. Interestingly, the $100 \mathrm{kyr}$ periodicity is not as pronounced if atmospheric $\mathrm{CO}_{2}$ concentrations are chosen below 190 ppmv or above $230 \mathrm{ppmv}$ in that study. Again, one may speculate about the role of $\mathrm{CO}_{2}$ and other greenhouse gases in changing the hysteresis curve of ice sheet growth and decay and their contribution to the transition from the $40 \mathrm{kyr}$ to the $100 \mathrm{kyr}$ world.

While a coarse resolution estimate of $\mathrm{CO}_{2}$ concentrations exists for glacial and interglacial periods over the MPT from boron isotopes in planktic foraminifera (Hönisch et al., 2009), an ultimate answer about the role of greenhouse gas climate forcing can only be derived from the atmospheric record archived in an Antarctic ice core covering this time interval. Accordingly, the international ice core community, as represented by the International Partnership for Ice Core Sciences (IPICS), has identified the quest for such an "Oldest-Ice" ice core as one of the most important scientific challenges in ice core research for the near future (http://www.pages.unibe.ch/ipics/white-papers).

Beyond the need to understand links between carbon dioxide and climate in the $40 \mathrm{k}$ world, there are many other compelling reasons for this old ice core record. The $40 \mathrm{k}$ world is defined primarily by the marine isotope record, which mainly reflects changes in global ice volume. The origin of the $40 \mathrm{kyr}$ signal may lie in the fact that summer insolation variations due to obliquity are in phase in the two hemispheres, whereas those due to precession are out of phase. This would cause canceling effects on marine isotopes between Northern Hemisphere and smaller-than-present Southern Hemisphere ice sheets, both driven by $23 \mathrm{kyr}$ precession cycles, but out of phase (Raymo et al., 2006). This Raymo et al. (2006) hypothesis makes the testable prediction that Antarctic temperature in the $40 \mathrm{k}$ world should have a strong precession signal, despite its absence in the marine record and only a direct Antarctic ice core temperature record will provide an answer to this question. Moreover, the mean Antarctic temperature from 1.5 Ma to $800 \mathrm{ka}$ is also of interest. The Raymo et al. hypothesis requires a slightly smaller, and presumably warmer, Antarctic ice sheet terminating largely on land. In the marine isotope record this period is near the end of a long-term trend believed to be due to the growth of Northern Hemisphere ice sheets (Zachos et al., 2001). Knowing mean Antarctic temperature and environmental conditions in the Southern Ocean region from isotopic and chemical ice core records over this time period would help us to understand potential changes in ice dynamics and the relationship between surface temperature and the marine isotope record. A $1.5 \mathrm{Myr}$ record might also contain evidence of the Jaramillo normal polarity event at about $1.0 \mathrm{Myr}$ as well as shorter term excursions known from the paleomagnetic timescale (Singer and Brown, 2002), providing an ice core view of two magnetic reversals, which would be recorded in a cosmogenic isotope ice core record 
covering that time interval (Raisbeck et al., 2006b). Moreover, this may provide chronological tie points to marine and terrestrial climate records via paleomagnetism.

However, finding such old ice in East Antarctica is not an easy task. Despite the fact that the East Antarctic ice sheet has existed continuously for much longer than 1.5 million yr, the flow of ice and subglacial melting due to geothermal heat make it difficult for such ice to survive. In this study we investigate which criteria such a drill site should fulfill to allow preservation of $1.5 \mathrm{Myr}$ old ice in the bottom $100 \mathrm{~m}$ of the ice sheet. In a second step we investigate, based on available glaciological and climatological data, where such criteria are currently fulfilled in East Antarctica, to constrain the potential study areas. This allowed us to identify broad focus areas, where there is a good chance that $1.5 \mathrm{Myr}$ old, stratigraphically undisturbed ice exists. At the end of this paper we lay out what the next steps are in terms of field work to characterize these study areas in sufficient detail to make an ultimate drill site selection based on robust information on the age and temperature at the base of the ice.

\section{Glaciological and geophysical boundary conditions}

\subsection{1-dimensional constraints}

The glaciological setting (thickness of the ice, accumulation rate, geothermal heat flux as well as vertical and horizontal flow) largely controls the possible age of the ice at the bottom of the ice sheet. In general higher ice thickness and lower accumulation rate favor old ice at the bottom. However, due to the balance of the geothermal heat flux and the vertical transport of heat by advection and heat conduction, low accumulation rates and high ice thickness also lead to warm ice and, thus, melting at the bottom as soon as the pressure melting point is reached. Although, steady melting may lower the risk of flow disturbances at the bottom (North Greenland Ice Core Project members, 2004), any melting leads to loss of ice, which strongly diminishes the age of the ice at the bottom. In principle a cold base can be sustained with relatively high geothermal heat flux as long as the accumulation rate is high enough or the ice thickness small enough. Vice versa, very low accumulation (or high ice thickness) can be compensated by a low geothermal heat flux to avoid bottom melting. From this discussion it becomes clear that the constraints of the age at the bottom by accumulation, ice thickness and geothermal heat flux are not independent of each other.

To illustrate the inter-relationships between these different parameters and give a first order estimate of the age of the ice at the bottom, we will use in the following a simple solution of the combined ice and heat flow equations (Paterson, 1994) using a 1-dimensional model to consistently describe both the thinning and melting of the ice for a given glaciological setting. In equilibrium the vertical velocity of the ice is given by the annual accumulation rate at the ice sheet surface and the boundary condition that the vertical velocity $w$ has to go to zero at the bottom of the ice $(z=0)$ if no melting occurs. Moreover, if the ice sheet is frozen to the bedrock (i.e., if no basal melting occurs), no deformation is possible at the bedrock, implying that also $\frac{\mathrm{d} w}{\mathrm{~d} t}(z=0)=0$.

The model is a simplified form of a 1-D flow model adapted from Ritz (1992) and Parrenin et al. (2007b). It fulfills the criteria given above and can be easily fitted to existing ice cores located on ice divide or dome positions. By way of fitting the model to the existing Dome $\mathrm{C}$ ice core age scale, we also take into account the special vertical flow conditions encountered at such an ice dome, which lead to much higher ice ages at the bottom compared to outflow regions (Martín and Gudmundsson, 2012). Note, however, that this model is too simple to describe sites where horizontal flow becomes important.

In the most general case, the vertical velocity profile is given in this model by

$w(z)=-\left(A-\frac{\partial H}{\partial t}-M\right)\left(\frac{z}{H}\right)^{m+1}-M$,

where $m$ is an adjustable exponent (form factor) close to 0.5 , $A$ the accumulation rate, $M$ the melt rate (both in meter ice equivalent per year) and the temporal gradient in ice thickness $H$ parametrizes potential changes in the thickness of the ice sheet.

Based on this vertical velocity profile, the age profile is given by

$t(z)=\int_{H}^{z} \frac{-1}{\left(A-\frac{\partial H}{\partial t}-M\right)\left(\frac{z}{H}\right)^{m+1}+M} \mathrm{~d} z$,

which can be numerically integrated. Note that $A, M$ and $H$ are all functions of time. In the following, however, we will assume that $A, M$ and $H$ are constant in time but use their long-term temporal averages. This implies that the depth-age relationship calculated from Eq. (2) will reproduce the general trend in the age but not the variations around the longterm mean.

The melt rate $M$ is defined by the difference in the geothermal heat flux at the bottom and the vertical heat transport by heat advection and heat conduction, which is determined largely by the temperature gradient and thermal conductivity at the bottom. The temperature profile in the ice (and thus also the bottom temperature gradient) can be calculated from the given velocity profile by solving the differential equation

$$
\frac{\partial T}{\partial t}=\frac{K}{\rho c} \frac{\partial^{2} T}{\partial z^{2}}+\left(\frac{1}{\rho c} \frac{\partial K}{\partial z}-w\right) \frac{\partial T}{\partial z},
$$

where $K$ is the thermal conductivity of the ice and $c$ its heat capacity and where we neglected the small amount of deformational heating due to shear deformation in this equation. The heat diffusivity is given by $\kappa=K / \rho c$, where $\rho$ is the 
density of ice. If we use constant values for $K, c$ and $\kappa$ over the entire ice column (for a discussion of these assumption see below), the steady-state solution is given by

$$
\begin{aligned}
T & =T_{\mathrm{S}}-C \int_{0}^{z} e^{-\frac{A-M}{\kappa H^{m+1}(m+2)} z^{m+2}-\frac{M}{\kappa} z} \mathrm{~d} z \\
& +C \int_{0}^{H} e^{-\frac{A-M}{\kappa H^{m+1}(m+2)} z^{m+2}-\frac{M}{\kappa} z} \mathrm{~d} z,
\end{aligned}
$$

where $T_{\mathrm{S}}$ is the surface temperature and $C$ is the temperature gradient at the bedrock, which is controlled by the vertical upward heat flux by conduction at the bottom given by the difference of the geothermal heat flux and the heat used for ice melting per unit time and square meter

$C=\frac{Q_{\mathrm{G}}-M \rho L_{\mathrm{m}}}{K}$.

where $L_{\mathrm{m}}$ is the specific latent heat for melting of ice.

The temperature profile in Eq. (3) can be calculated directly by numerical integration if the bottom temperature stays below the pressure melting point. In the case that the bottom temperature becomes higher than the pressure melting point, we increased the melt rate in our model in small increments of $0.01 \mathrm{~mm}$ ice equivalent (IE) per year until the bottom temperature reached the pressure melting point. In this way we obtained a steady-state temperature profile consistent with the prescribed geothermal heat flux and the vertical velocity profile. Accordingly, the melt rate is directly controlled by the geothermal heat flux and the chosen accumulation rate and ice thickness.

To illustrate the performance of this simple model and its applicability to a future Oldest-Ice coring site we applied it to the EPICA (European Project for Ice Coring in Antarctica) Dome C (EDC) ice core, which represents the Oldest-Ice core to date. Instead of changing accumulation, ice thickness and surface temperature over time, we used the average values over the last $800000 \mathrm{yr}(A=0.0191 \mathrm{~m}$ ice equivalent per year, $H=3151 \mathrm{~m}$ ice equivalent and $T_{\mathrm{S}}=213 \mathrm{~K}$ ) as given by ice core proxy data (Parrenin et al., 2007a, b; Jouzel et al., 2007; EPICA community members, 2004) to drive the model. Note that all these values are slightly lower than the present interglacial values encountered at the Dome C site. The geothermal heat flux is not known a priori and was used as a fitting parameter, which is controlled by the bottom age known from the EDC ice core record.

To illustrate the sensitivity on the form factor $m$, we performed three runs with $m=0.3, m=0.5$ and $m=0.7$. As illustrated in Fig. 1, the temperature profile is only slightly affected by this choice. However, the form factor has a strong influence on the age profile of the ice. In the following we will use $m=0.5$, which is in very good agreement with the EDC3 age scale (Parrenin et al., 2007a) derived for the EPICA ice core at Dome C. Note that our heat flow model
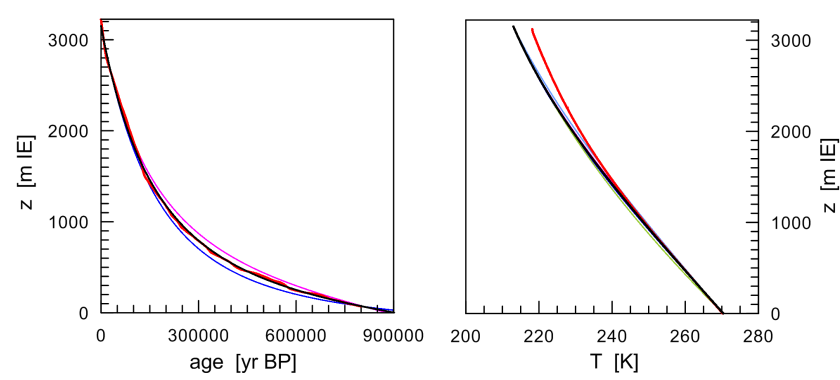

Fig. 1. Left: comparison of the EDC3 age scale (red) (Parrenin et al., 2007a) and the modeled age scale using the simple 1-D model with $m=0.5$ (black), $m=0.3$ (blue) and $m=0.7$ (purple). Right: comparison of the measured Dome $\mathrm{C}$ temperature profile (red) and the modeled temperature profile using the 1-D model for $m=0.5$ with constant thermal conductivity $K$ and heat capacity $c$ at the bottom temperature $T_{\mathrm{b}}=270.4 \mathrm{~K}$ (black), at the measured mean temperature over the entire ice column $T_{\mathrm{m}}=240.9 \mathrm{~K}$ (blue) and using temperature dependent $K$ and $c$ (green). Also shown are versions with constant $K$ and $c$ using the bottom temperature, but for $m=0.3$ (blue) and $m=0.7$ (purple), which are very similar to the one for $m=0.5$.

in Eq. (3) assumes no horizontal advection of heat, i.e., we assume a perfect dome position. In case of EDC, where horizontal surface velocities are on the order of a few centimeters per year (Vittuari et al., 2004), this criterion seems to be reasonably fulfilled. We will also use $m=0.5$ for all our later calculations, essentially assuming that any potential OldestIce coring site will also be located on a dome and will have flow conditions similar to Dome C. Note that other sites with more complex flow conditions (for instance in outflow regions) would require different thinning functions, thus different exponents.

The obtained value for $Q_{\mathrm{G}}$ is of course dependent on the values used for the heat conduction and heat capacity, which are dependent on temperature. In our simple flow model we assumed a constant value for $K$ and $c$. We use $K$ and $c$ at the temperature of the pressure melting point (for example $270.4 \mathrm{~K}$ at Dome C), which effectively determines the bottom gradient of the temperature profile and thus the upward heat flux at the bottom. This will lead to a better estimate for the required melting but compromises the resemblance of the modeled temperatures over the entire ice column with the measured temperature profile. For $m=0.5$ this assumption leads to a required geothermal heat flux at Dome $\mathrm{C}$ of $Q_{\mathrm{G}}=53.5 \mathrm{~mW} \mathrm{~m}^{-2}$ and an age at $70 \mathrm{~m}$ ice equivalent above bedrock (i.e., approximately at the height above bedrock, where the last unambiguously stratified ice has been identified in the EDC ice core) of $803 \mathrm{kyr}$ in good agreement with the EDC3 age scale (Parrenin et al., 2007a). The required melt rate obtained by the model of $0.68 \mathrm{~mm}$ ice equivalent (IE) per year is only slightly larger than the $0.66 \mathrm{~mm}$ IE per year derived by Parrenin et al. (2007b) using a more complex 1-dimensional flow model, which also takes temporal 
changes in the ice thickness into account. In case of $m=0.3$ and $m=0.7$, where the Dome C age profile was not well reproduced, the geothermal heat flux required to set the bottom age at Dome $\mathrm{C}$ correctly is 51.0 and $55.6 \mathrm{~mW} \mathrm{~m}^{-2}$, respectively (i.e., $Q_{\mathrm{G}}$ changes by less than $5 \%$ in the three runs).

The modeled temperature profile in Fig. 1 shows a reasonable resemblance with the measured profile in the lower half of the ice sheet, given our simple thinning function and using our time-averaged approach. Using $K$ and $c$ values at the mean measured temperature over the entire ice column $(240.9 \mathrm{~K})$ improves the resemblance of the temperature profile in the bottom half of the ice sheet (Fig. 1), but $Q_{\mathrm{G}}$ is about $10 \%$ higher as the lower temperature leads to a higher heat conduction at the bedrock. In the upper half of the ice sheet both solutions significantly deviate from the measured temperature profile. This is to be expected, as we did not include temporal changes in the surface temperature in our model. Accordingly, the Holocene warming is the reason for the warmer measured temperatures in the top half of the ice sheet compared to our model results.

To test the influence of our assumption of a vertically constant thermal conductivity and heat capacity, we also used a numerical (computationally more expensive) model to obtain the full steady-state solution of Eq. (3), where $K$ and $c$ were allowed to vary with temperature, but still using the temporal mean accumulation rate and ice thickness. In this version of the model, the temperature profile deviates somewhat from the one using constant $K$ and $c$ (see Fig. 1) as thermal conductivity and heat capacity change with depth. In line, we obtain a $10 \%$ higher bottom temperature gradient but also a $10 \%$ higher geothermal heat flux. The melt rate is of course the same as the one in the case of constant $K$ and $c$ above, as it is selected to fit the age $70 \mathrm{~m}$ above bedrock. Note that the numerical temperature profile in the bottom part is also slightly different from the measured profile at Dome C (Fig. 1), showing that our steady-state 1-D model cannot explain all of the features of the Dome $\mathrm{C}$ temperature record.

In view of the good correspondence of the bottom temperature gradient in our simple model (using constant $K$ and $c$ at the pressure melting point) with that measured at Dome $\mathrm{C}$, we believe that our simple 1-D model is sufficient to estimate the potential age of a future Oldest-Ice core and to illustrate the dependence of bottom age on the various glaciological parameters. Note, however, that the derived absolute value for the geothermal heat flux is model dependent and that the model result is effectively calibrated to the conditions at the Dome C site. In summary, the choice of the model has no significant influence on the main conclusions of our paper regarding the influence of glaciological parameters on the bottom age of the ice; however, caution has to be taken when comparing the absolute value of the derived geothermal heat flux in our model with values derived by other approaches. In the following, we will not stress the absolute value of the geothermal heat flux derived in our model, but its deviation from the value found at Dome $\mathrm{C}$. This is a reasonable
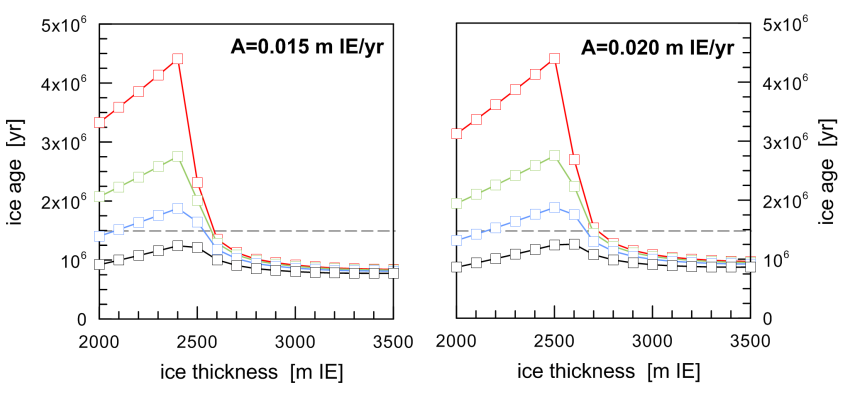

Fig. 2. Age of the ice at the bottom of the ice sheet for different ice thickness, but constant mean accumulation rate of $A=$ $0.015 \mathrm{~m} \mathrm{IE} \mathrm{yr}^{-1}$ (left) and $A=0.02 \mathrm{~m} \mathrm{IE} \mathrm{yr}^{-1}$ (right) using a constant mean surface temperature of $213 \mathrm{~K}$ and a geothermal heat flux of $55 \mathrm{~mW} \mathrm{~m}^{-2}$. The colors indicate the age $10 \mathrm{~m}$ above bedrock (red), $25 \mathrm{~m}$ above bedrock (green), $50 \mathrm{~m}$ above bedrock (blue), and $100, \mathrm{~m}$ above bedrock (black). The grey dashed line indicates the 1.5 Myr age threshold.

approach as the true site-specific geothermal heat flux is virtually unknown within Antarctica anyway (Pollard and DeConto, 2005) and we do not know the absolute value of the geothermal heat flux at a future Oldest-Ice coring site. Moreover, we want to stress that the results for a future Oldest-Ice ice coring site based on our simple model assume that the flow conditions at that site are similar to that at Dome C. This appears to be a reasonable first order assumption to study the general dependence of the age of the ice close to the bottom, but cannot replace a more refined time dependent 3-D model exercise of ice and heat flow using detailed bedrock, temperature and accumulation information to be gained from future dedicated reconnaissance studies.

With our simple tool at hand, we can now look into the general systematic dependence of bottom ages with ice thickness, accumulation rate and geothermal heat flux. To this end we use the 1-D model over a wide range of these parameters. In a first experiment we varied the ice thickness from 2000 to $3500 \mathrm{~m}$ ice equivalent, while keeping the accumulation and geothermal heat flux constant. For $Q_{\mathrm{G}}$ we use a standard value of $55 \mathrm{~mW} \mathrm{~m}^{-2}$ a little higher than the one derived for Dome $\mathrm{C}$, for the mean accumulation we use a value of $0.015 \mathrm{~m} \mathrm{IE} \mathrm{yr}^{-1}$ (i.e., about $20 \%$ lower than for EDC) and alternatively a value of $0.02 \mathrm{~m} \mathrm{IE} \mathrm{yr}^{-1}$ (i.e., a little higher than EDC). The chosen surface temperature is very close to the mean temperature at the EDC site $\left(T_{\mathrm{s}}=213 \mathrm{~K}\right)$.

As illustrated in Fig. 2, the age of the ice is extremely sensitive to the occurrence of bottom melting, which starts to occur at an ice thickness larger than $2400 \mathrm{~m}$ IE for the given geothermal heat flux of $55 \mathrm{~mW} \mathrm{~m}^{-} 2$ and an accumula-

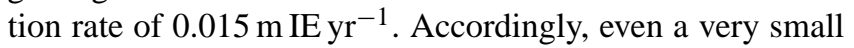
amount of bottom melting will strongly decrease the chance to find $1.5 \mathrm{Myr}$ old ice well above the bedrock. If the accumulation rate is higher bottom melting occurs at somewhat higher ice thicknesses, because downward advection of cold 
ice is larger. Conversely, at depths where no bottom melting occurs, the lower accumulation of $0.015 \mathrm{~m} \mathrm{IE} \mathrm{yr}^{-1}$ leads to about $20 \%$ higher ages at the same depth than the solution for $0.02 \mathrm{~m} \mathrm{IE} \mathrm{yr}^{-1}$ due to reduced thinning. In conclusion, bottom melting should be clearly avoided to find $1.5 \mathrm{Myr}$ old ice.

For the geothermal and accumulation conditions encountered at Dome C, ice thickness would have to be lower than or equal to $2600 \mathrm{~m}$ to safely avoid ice loss by bottom melting. Note, that due to ice thinning the chosen values for accumulation and ice thickness limit the height above bedrock at which such old ice can be found even if no melting occurs. In none of the model solutions in Fig. 2 can we find 1.5 million yr old ice above $100 \mathrm{~m}$ from the bedrock and even to find such old ice $50 \mathrm{~m}$ above bedrock, one has to stay within a narrow ice thickness window of $2100-2500 \mathrm{~m}$ of ice equivalent. These observations become critical as disturbances of bottom ice are regularly observed in deep ice cores. Even at Dome C, which is located on a dome and which is subject to some bottom melting today, the bottom $70 \mathrm{~m}$ appear to be subject to disturbances of the ice, showing a clear lack of glacialinterglacial cycles. A potential lateral movement of the dome position over time may contribute to these disturbances.

The risk of bottom melting becomes especially worrisome since the ice thickness changes over time, which has not been included in our simple model exercise. Warm interglacial periods are characterized by $50-200 \mathrm{~m}$ thicker ice for most of the plateau regions of the East Antarctic ice sheet than cold glacial periods (Parrenin et al., 2007b; Ritz et al., 2001; Huybrechts, 2002) increasing the risk of intermittent bottom melting. This may be especially critical for very warm interglacial periods such as marine isotope stage (MIS) 5.5 or MIS 11, where surface temperatures were 3$5^{\circ} \mathrm{C}$ warmer than in the Holocene (EPICA community members, 2006; Jouzel et al., 2007). Thus, warm interglacial conditions with higher ice thicknesses in principle favor bottom melting, although the time constant for the temperature profile to achieve a new equilibrium is typically longer than the duration of an interglacial. To calculate an upper limit of the effect of warmer interglacial periods in the past, we performed a run with $Q_{\mathrm{G}}=55 \mathrm{~mW} \mathrm{~m}^{-2}$, in which we increased the accumulation rate to $0.03 \mathrm{~m} \mathrm{IE} \mathrm{yr}^{-1}$ for the entire time and increased the mean surface temperature by $5^{\circ} \mathrm{C}$. In this case $1.5 \mathrm{Myr}$ old ice is only found for ice thicknesses lower than $2500 \mathrm{~m}$ IE and only in the bottom $10-15 \mathrm{~m}$. This is not a realistic estimate since the accumulation rate was clearly not constant at a warm interglacial level throughout the last 1.5 million years. If we use a $5^{\circ} \mathrm{C}$ warmer surface temperature, but leave the mean snow accumulation at $0.02 \mathrm{~m} \mathrm{IE} \mathrm{yr}^{-1}$ as above, the maximum ice thickness that avoids bottom melting reduces to $2300 \mathrm{~m}$, but 1.5 million yr old ice is then found at $25-40 \mathrm{~m}$ above bedrock. Again, we feel that this represents too conservative an estimate, because the bottom temperature gradient (that controls the upward heat transport by conduction) will only vary very slightly by an interglacial

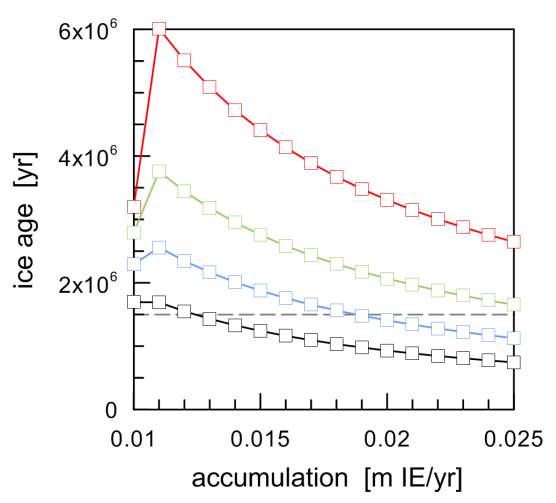

Fig. 3. Age of the ice at the bottom of the ice sheet for different mean accumulation rates but constant ice thickness of $2400 \mathrm{~m}$ IE using a constant mean surface temperature of $213 \mathrm{~K}$ and a geothermal heat flux of $55 \mathrm{~mW} \mathrm{~m}^{-2}$. The colors indicate the age $10 \mathrm{~m}$ above bedrock (red), $25 \mathrm{~m}$ above bedrock (green), $50 \mathrm{~m}$ above bedrock (blue), and $100 \mathrm{~m}$ above bedrock (black). The grey dashed line indicates the 1.5 Myr age threshold.

warming lasting on the order of a few $10000 \mathrm{yr}$, because the timescale to achieve a steady-state temperature profile is of similar order. Clearly, the choice of an Oldest-Ice coring site should err on the safe side to avoid bottom melting at any point in the past $1.5 \mathrm{Myr}$. Accordingly, our 1-D model suggests a site, where the ice thickness is smaller than or equal to $2500 \mathrm{~m}$ if the geothermal heat flux and the accumulation are comparable to the case at Dome C. Of course sites with a lower $Q_{\mathrm{G}}$ allow for higher ice thicknesses (see discussion below). Note, however, that our approach is only intended to constrain potential study regions, while for the final drill site selection 3-dimensional ice and heat flow model exercises have to be performed.

In a second experiment, we used an ice thickness of $2400 \mathrm{~m} \mathrm{IE}$, a geothermal heat flux of $55 \mathrm{~mW} \mathrm{~m}^{-2}$ and a surface temperature of $213 \mathrm{~K}$, but changed the accumulation rate to see how large the accumulation rate can be without compromising the bottom age. As illustrated in Fig. 3, even a mean accumulation rate of $0.019 \mathrm{~m} \mathrm{IE} \mathrm{yr}^{-1}$ (i.e., comparable to the accumulation encountered at EDC) still provides 1.5 million yr old ice at about $50 \mathrm{~m}$ above bedrock at this low ice thickness. However, to reach this age at $100 \mathrm{~m}$ above bedrock the mean accumulation rate has to be lower than $0.012 \mathrm{~m} \mathrm{IE} \mathrm{yr}^{-1}$. Such low accumulation rates are unlikely to be found in regions of the East Antartic plateau with continuous snow deposition. Note in Fig. 3 that if the accumulation rate is chosen to be $0.01 \mathrm{~m} \mathrm{IE} \mathrm{yr}^{-1}$ or smaller, bottom melting sets in for the chosen ice thickness and geothermal heat flux. As stated above, the height above bedrock where old ice is encountered is a critical issue, because the chance for flow disturbances becomes greater the closer the ice is to the bedrock. Accordingly, higher accumulation rates impose 


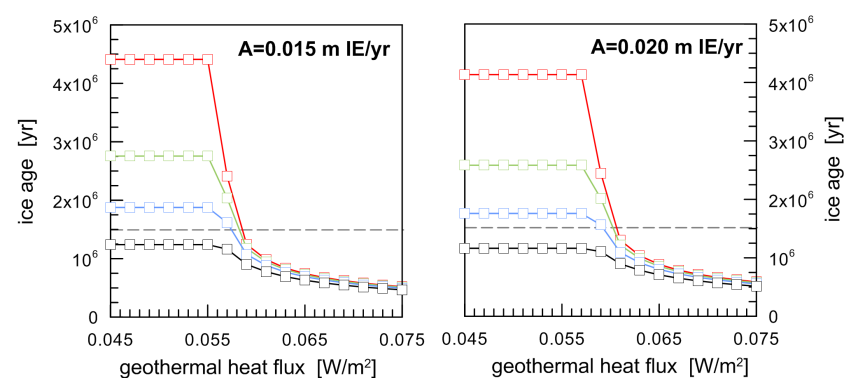

Fig. 4. Age of the ice at the bottom of the ice sheet for different geothermal heat flux but constant mean accumulation rate of $A=$ $0.015 \mathrm{~m} \mathrm{IE} \mathrm{(left)} \mathrm{and} A=0.02 \mathrm{~m} \mathrm{IE} \mathrm{(right).} \mathrm{Ice} \mathrm{thickness} \mathrm{was} \mathrm{kept}$ constant at $2400 \mathrm{~m} \mathrm{IE}$ and a constant mean surface temperature of $213 \mathrm{~K}$ was used. The colors indicate the age $10 \mathrm{~m}$ above bedrock (red), $25 \mathrm{~m}$ above bedrock (green), $50 \mathrm{~m}$ above bedrock (blue), and $100 \mathrm{~m}$ above bedrock (black). The grey dashed line indicates the 1.5 Myr age threshold.

more stringent requirements on horizontal flow and flatness of the bedrock topography to avoid such disturbances.

While the low-resolution changes in ice thicknesses and snow accumulation rates are reasonably known for the Antarctic for most areas, the major unknown is the geothermal heat flux. To test the sensitivity of the bottom age to this parameter we varied it in a third experiment, while keeping the ice thickness at $2400 \mathrm{~m}$ IE. For the surface temperature we used again $213 \mathrm{~K}$. We performed two alternative sets of runs with an accumulation rate at $0.015 \mathrm{~m} \mathrm{IE} \mathrm{yr}^{-1}$ and $0.02 \mathrm{~m} \mathrm{IE} \mathrm{yr}^{-1}$. As illustrated in Fig. 4, $Q_{\mathrm{G}}$ becomes the crucial parameter, since the necessary bottom age is only reached if no bottom melting occurs. In the higher accumulation rate case, bottom melting sets in if $Q_{\mathrm{G}}>57 \mathrm{~mW} \mathrm{~m}^{-2}$, in the low accumulation rate case if $Q_{\mathrm{G}}>55 \mathrm{~mW} \mathrm{~m}^{-2}$. Accordingly, the critical geothermal heat flux for bottom melting for such an Oldest-Ice site with only $2400 \mathrm{~m}$ ice thickness and $2 \mathrm{~cm} \mathrm{IE} \mathrm{yr}^{-1}$ is only about $6 \%$ higher than the case for EDC and only $3 \%$ in the low accumulation case. The essence of the results of this exercise is that special care has to be taken to determine the temperature and, thus, the geothermal heat flux at the base of the ice sheet before choosing a future Oldest-Ice core site in order to avoid bottom melting.

The results in Fig. 4 show that for a fixed ice thickness of $2400 \mathrm{~m}$ all sites with a geothermal heat flux below $57 \mathrm{~mW} \mathrm{~m}^{-2}$ and an accumulation rate of only $0.015 \mathrm{~m} \mathrm{IE} \mathrm{yr}^{-1}$ (below $59 \mathrm{~mW} \mathrm{~m}^{-2}$ if the accumulation rate is $0.02 \mathrm{~m} \mathrm{IE} \mathrm{yr}^{-1}$ ) provide $1.5 \mathrm{Myr}$ old ice at about $50 \mathrm{~m}$ above bedrock in our model. However, if the geothermal heat flow is lower than that, one can allow a higher ice thickness at a future Oldest-Ice drill site. Accordingly, in our last experiment we determined the maximum geothermal heat flux that allows $1.5 \mathrm{Myr}$ old ice at least $50 \mathrm{~m}$ above bedrock for a given ice thickness between 2000 and $3500 \mathrm{~m}$. Again we use an accumulation rate of either 0.015 or $0.02 \mathrm{~m} \mathrm{IE} \mathrm{yr}^{-1}$. The results of this experiment show a slightly non-linear relationship between geothermal heat flux and maximum allowed ice

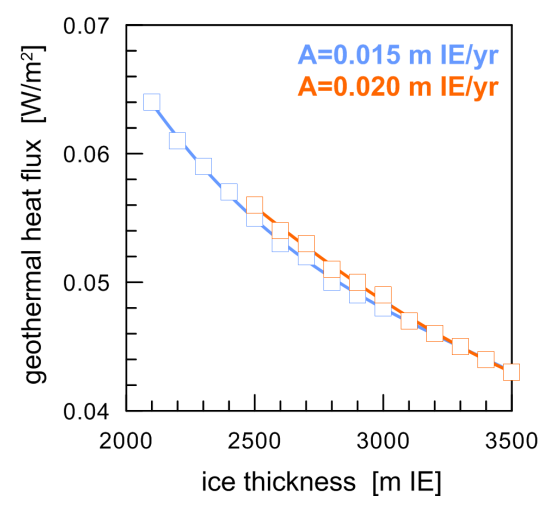

Fig. 5. Dependence of the maximum allowed ice thickness and the geothermal heat flux to obtain $1.5 \mathrm{Myr}$ old ice at least $50 \mathrm{~m}$ above bedrock using a constant mean surface temperature of $213 \mathrm{~K}$. The colors indicate the case for a mean accumulation rate of $A=$ $0.015 \mathrm{~m} \mathrm{IE} \mathrm{yr}^{-1}$ (blue) and $A=0.02 \mathrm{~m} \mathrm{IE} \mathrm{yr}^{-1}$ (orange).

thickness in Fig. 5, where the sensitivity to geothermal heat flux is somewhat lower in the low accumulation rate case. However, in both accumulation cases even a $3000 \mathrm{~m}$ long ice core is feasible as long as $Q_{\mathrm{G}}$ is below $49 \mathrm{~mW} \mathrm{~m}^{-2}$. In case of Dome $\mathrm{C}$ where the mean ice thickness in the past was about $3150 \mathrm{~m}$ of ice equivalent and the mean accumulation rate was $0.019 \mathrm{~m} \mathrm{IE} \mathrm{yr}^{-1}$, the geothermal heat flux would have to be lower than $47 \mathrm{~mW} \mathrm{~m}^{-2}$ to allow for $1.5 \mathrm{Myr}$ old ice at $50 \mathrm{~m}$ above bedrock. As the local geothermal heat flux is largely unknown for the Antarctic ice sheet away from recent ice core drilling sites, it becomes clear that this parameter represents a crucial gap in our knowledge for a wellinformed selection of a future Oldest-Ice ice core and requires dedicated field measurements in the future (see also below).

\subsection{2-dimensional constraints}

In the discussion above we have neglected any horizontal flow of the ice other than the implicit divergence imposed by the decreasing vertical velocity $w$ as the bed is approached. Apart from its influence on the age profile in the ice, horizontal flow is especially worrying as it imposes the risk of flow disturbances. As illustrated by the Vostok (Raynaud et al., 2005; Parrenin et al., 2001), EPICA Dronning Maud Land (EDML) (Ruth et al., 2007; EPICA community members, 2006) and NEEM (NEEM community members, 2013) ice cores, which are all located several hundred kilometers downstream of the initial site of snow deposition for deep, old ice, such flow disturbances are a common phenomenon in the bottom of these ice cores and can affect a few hundred meters of ice at the bottom. To initiate such flow disturbances both strong bedrock undulations as well as the occurrence of bottom melting at any upstream location may contribute. In case of ice frozen to bedrock, the bottom drag leads to strong shear deformation, increasing the chance of flow 
disturbances, especially if the rheology of the ice changes in the core from glacial to interglacial ice (NEEM community members, 2013). In the case of an upstream switch from frozen to liquid based ice, such a slip/stick situation may be also favorable for overturning of ice layers leading to folds (Wolovick et al., 2012). Moreover, downstream refreezing of melt water that was formed upstream, as suggested by Bell et al. (2011) based on ice radar measurements, can further compromise the age of the ice at the bottom. This may be especially important in regions of high horizontal flow and pronounced bedrock topography. Importantly, our model above does not take into account the bedrock topography. Future more refined modeling efforts have to take advantage of the new high-resolution bedrock topography (Fretwell et al., 2013) and other ongoing or future radar campaigns.

Thus, not only should the local glaciological and geothermal conditions of a future Oldest-Ice site be favorable to find 1.5 million yr old ice, but also the entire glaciological conditions along the upstream flow line of the ice have to be taken into account. This becomes especially important when considering that even for a horizontal flow velocity of only $1.0 \mathrm{~m} \mathrm{yr}^{-1}$, which is easily reached at any downstream position, the ice at the bottom has travelled around $1000(!) \mathrm{km}$ horizontally, where most of the time the ice was located close to the bedrock, increasing the chances for flow disturbances.

The discussion above shows that regions of strong bottom drag have to be avoided for frozen ice. At the same time a low bottom drag does not necessarily imply a small chance of flow disturbances or old ice, because regions with very low bottom drag usually indicate bottom melting. An example is illustrated in Fig. 6 by the clear depiction of Lake Vostok in a reconstruction of the bottom drag, using information on surface and bottom topography. This shows that only regions very close to dome positions provide the necessary low basal drag (Arthern and Gudmundsson, 2010) because of low horizontal velocities, while at the same time avoiding long horizontal travel distances and bottom melt. Note that the selection of a dome position alone is also not sufficient to find old, well-stratified ice as illustrated by the flow disturbances encountered at GRIP and GISP2 in Greenland (Grootes et al., 1993). Only sites in the vicinity (about $50-100 \mathrm{~km}$ ) of a dome or saddle, where ice thickness is low enough and where bedrock topography is reasonably smooth appear to be good candidates. Accordingly, reasonably flat subglacial highlands with a rather limited maximum ice thickness would provide ideal conditions for an Oldest-Ice ice core. As shown above, ice thickness should not exceed $2500 \mathrm{~m}$, if we assume the same geothermal conditions as at Dome C. To complicate things further, dome and ice divide locations may also have moved by tens of kilometers over time despite their forcing by bedrock undulations. Thus, a more detailed reconnaissance of dome and potentially saddle positions is essential to get high resolution information on bedrock topography, ice thickness, internal radar layer stratigraphy and the temperature at the base of the ice.

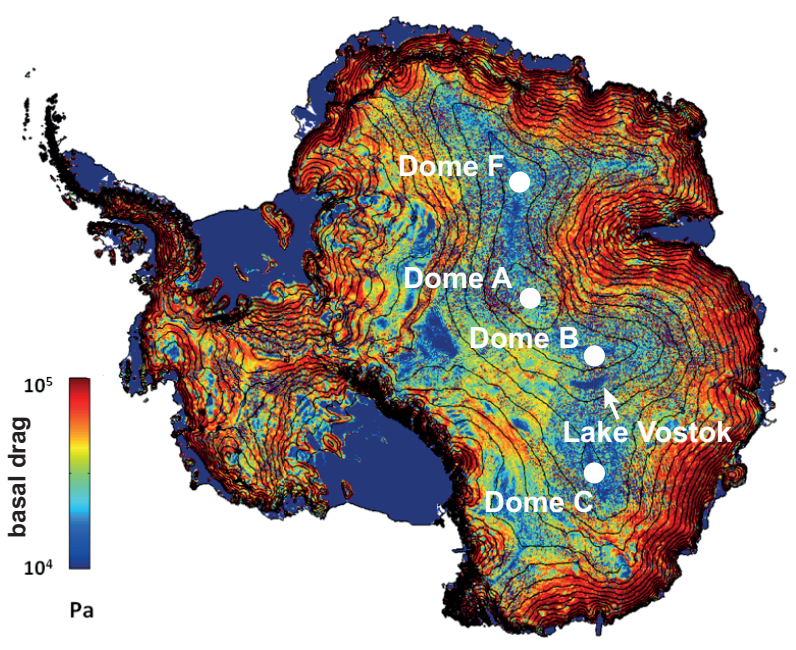

Fig. 6. Basal drag reconstruction for the Antarctic ice sheet (Arthern and Gudmundsson, 2010) showing areas of low drag due to liquid at the ice-bedrock interface (e.g., Lake Vostok as indicated by the white arrow) or due to low horizontal velocities.

\section{Glaciological boundary conditions: state of knowledge}

As outlined above, snow accumulation, ice thickness as well as bottom conditions (bedrock topography and melting) largely determine the age of the ice at the bottom. In the following we will summarize the state-of-the-art of the knowledge on these parameters to make recommendations on what has to be done in the future for the ultimate selection of a final Oldest-Ice core site (see Sect. 4).

\subsection{Snow accumulation rate}

As outlined above snow accumulation has to be very low to allow the existence of old ice at the bottom of the ice sheet in sufficient resolution and well above bedrock. By sufficient resolution, we mean that each $41 \mathrm{kyr}$ cycle should be contained in no less than two meters of ice (i.e., no more than $20000 \mathrm{yr}$ per meter). This criterion minimizes the possibility that greenhouse gases will have been homogenized by diffusion (Bereiter et al., 2013). Accordingly, any potential future Oldest-Ice coring site has to be located in the interior of the East Antarctic ice sheet, where snow accumulation rates lower than $0.03 \mathrm{~m} \mathrm{IE} \mathrm{yr}^{-1}$ are found under present conditions. Luckily, in the interior of the Antarctic ice sheet, where surface gradients are low, the large-scale accumulation distribution is sufficiently known from field observations and microwave satellite imaging (Arthern et al., 2006). In contrast to coastal low accumulation sites, which are mainly caused by wind erosion, the domes and ridges of the interior region of the East Antarctic plateau are characterized by relatively low wind speeds and, thus, a quasi-continuous deposition of snow fall/diamond dust events can be expected. 

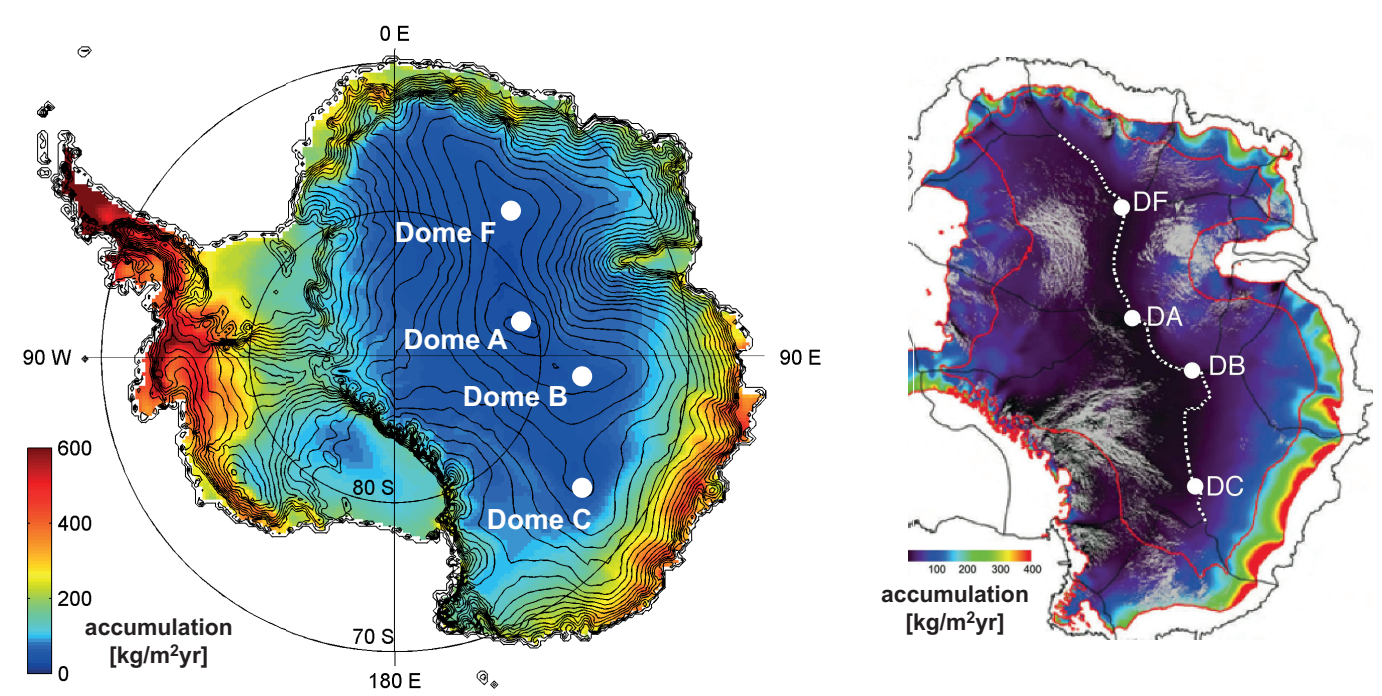

Fig. 7. (Left) compilation of surface accumulation rate of the Antarctic ice sheet using pointwise field data and total coverage microwave radar information (Arthern et al., 2006); (right) regions of wind glazing (indicated by grey shading) in areas on the East Antarctic Plateau (Scambos et al., 2012; Das et al., 2013).

Figure 7 illustrates that essentially all the ice divide positions on the East Antarctic plateau above about $3000 \mathrm{~m}$ a.s.l. fulfill this criterion. There is a general trend of lower accumulation rates with higher altitudes (thus lower water vapor content). Moreover, field observations close to those dome positions previously used for deep ice core drillings show that locations on the lee side of the dome with respect to the main wind direction tend to have even smaller accumulation rates than the dome itself. Accordingly these positions may be favorable compared to the dome, if the ice thickness is low enough.

Based on satellite images and field observations the occurrence of megadunes has been documented in some parts of the East Antarctic Plateau. These dunes occur in regions of low accumulation and sufficient surface gradients to support strong katabatic flow, and are characterized by severe sublimation features in the snow pack (Severinghaus et al., 2010). While such features affect the diffusive transport of gases within the top of the firn column, they do not corrupt the gas records in the ice per se. Another surface feature of the East Antarctic ice sheet is snow scouring leading to wind glazing that can be identified using satellite images (Das et al., 2013; Scambos et al., 2012). This wind scouring may cause persistent loss of snow accumulation and potentially create hiatuses in a potential Oldest-Ice ice core. However, dome or saddle positions, which we prefer for the selection of an Oldest-Ice coring site (see above), are characterized by small surface gradients and low wind speeds and, thus, are also unlikely to be affected by megadune formation or wind glazing (Fig. 7b).

While the large-scale accumulation distribution is sufficiently known, small-scale accumulation oscillations over tens of kilometers are observed in radar measurements superimposed on the climatological trends (Eisen et al., 2005, 2008; Fujita et al., 2011). These oscillations reflect the bedrock topography underneath the ice. Since the surface is essentially flat, while bedrock undulations can be several hundreds of meters high, snow re-distribution tends to smooth out the altitude variations despite constant meteorological precipitation rates on these spatial scales. Accordingly, surface accumulation rates can vary by $10-20 \%$ around the large-scale mean in some regions. To quantify these variations, 3-dimensional high-resolution snow radar measurements around a potential Oldest-Ice deep coring site should be performed.

\subsection{Ice thickness and bedrock topography}

Information on ice thickness and bedrock topography is largely based on ground-based or airborne ice penetrating radar measurements, which in most cases are constrained due to logistical reasons to flight lines out of coastal stations and to surface expeditions. Accordingly, it is a major task to assemble this information from the various data sources. Only recently an updated bedrock and ice thickness compilation for Antarctica (BEDMAP2) has been made available (Fretwell et al., 2013), which substantially improves the resolution and allows improved screening of potential OldestIce sites. Note that the grid resolution for the ice thickness in this hugely improved data set is at maximum $5 \mathrm{~km}$ and that the resolution of the available ice thickness data is still much lower in many areas (Fretwell et al., 2013). As illustrated in Fig. 8 many of the dome regions exceed an ice thickness of $2400 \mathrm{~m}$, however, low ice thickness (but rough bedrock topography, see below) exists around Dome A. Around the current Dome F and Dome C sites, and the saddle connecting 

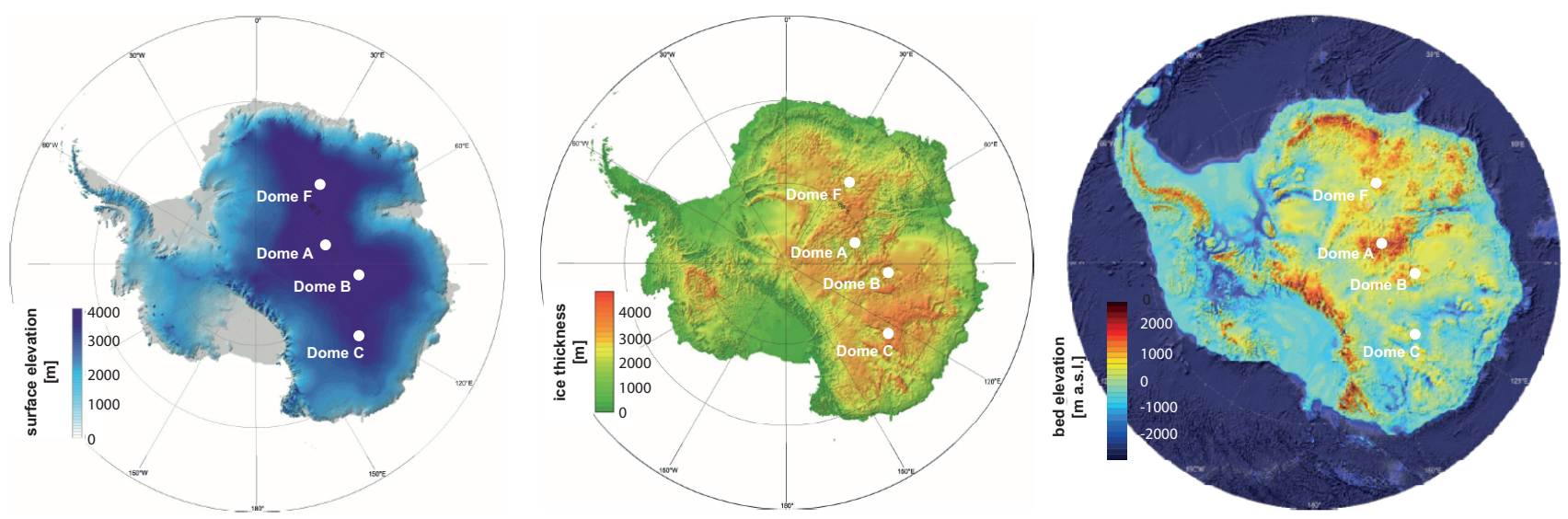

Fig. 8. BEDMAP2 surface grid (left), ice thickness grid (middle) and bedrock topography (right) (Fretwell et al., 2013).

Dome F and A as well as on Ridge B upstream of Vostok, regions with lower ice thicknesses exist, however, they may be quite localized and due to the significant bedrock topography may be more prone to flow disturbances in the very bottom part of the ice.

Note that some areas in the bedrock reconstruction in Fig. $8 \mathrm{~b}$ (such as the Aurora Basin) appear to be smoother than others. In most cases, however, this does not imply a lack of bedrock undulations, but reflects mainly the lower resolution of the available data that goes into the reconstruction in these regions. Thus despite its huge step forward, the information of BEDMAP2 is only sufficient to screen major areas for their suitability for an Oldest-Ice coring site, but it cannot replace future high resolution radar reconstructions in the vicinity of a potential coring site. The latter should also include the evaluation of internal horizons in the radargrams, to allow a 3-D reconstruction of ice flow in this region.

\subsection{Geothermal heat flux and bottom melting}

Due to lack of direct measurements, undoubtedly the most difficult parameter to constrain is the geothermal heat flux and with it the occurrence of basal melting. In fact reliable information on the geothermal heat flux is only available for already existing ice coring sites, where borehole temperature profiles allow a reliable reconstruction of the bottom temperature. This available information (as well as the occurrence of unexpected basal water during penetration of the ice sheet at EDML) indicate that most of the deep drilling sites in East Antarctica are currently located at sites where basal melting occurs. This is intrinsically the case, because for these deep drilling sites large ice thicknesses $(>2500 \mathrm{~m} \mathrm{IE}$ ) have been preferred to obtain highest resolution at depth.

Indirect evidence of basal melting exists from the imprint of subglacial lakes in the surface topography of the ice sheet and from recent progress in the evaluation of ice penetrating radar measurements (Fujita et al., 2012) that allow the identification of liquid water at the base using the higher backscatter signal where liquid water is present. The study by Fujita et al. (2012) shows that in many areas of the high plateau regions of Dronning Maud Land between Dome F and the EDML drill site, the ice sheet is water based. In the inland regions, this is mainly due to the high ice thickness, and only sites where the ice thickness is lower than approximately $2400 \mathrm{~m}$ appear not to be affected by basal melting in keeping with our model exercise. Note that this good agreement may be only coincidental, since the geothermal heat flux in the Dronning Maud Land area may be different compared to the EDC region, which is close to the one we used in the 1-D model. Some spatial variability in the geothermal heat flux is also indicated by a reconstruction by Pattyn (2010). Thinner coastal ice is not affected by basal melting (except for fast moving ice streams), however, those regions are subject to very rapid thinning at the bottom and $1.5 \mathrm{Myr}$ old ice is expected to be extremely close to the bedrock, thus most likely subject to flow disturbances.

Overall about $55 \%$ of the ice radar lines studied by Fujita et al. (2012) showed potential melt at the bottom. This may be regarded as a minimum estimate as other processes (such as scattering of the signal due to bedrock roughness or anomalous damping of the signal in the ice or at the bed) may give false negatives for the presence of water at the bottom. However, this number is approximately in line with model based reconstructions (Fig. 9) (van Liefferinge and Pattyn, 2013; Pattyn, 2010), who combined the geological information on the geothermal heat flux for certain rock types occurring at the base of Antarctica with the localized information of subglacial lakes and an ice sheet model to constrain bottom melting and the age of the ice at the bottom. Based on this model exercise geothermal heat fluxes between 40 and $70 \mathrm{~mW} \mathrm{~m}^{-2}$ are derived for the bedrock underneath the plateau region of the East Antarctic ice sheet. The value derived for EDC in our 1-D model lies well within this range. However, we urge caution in interpreting these model results, 


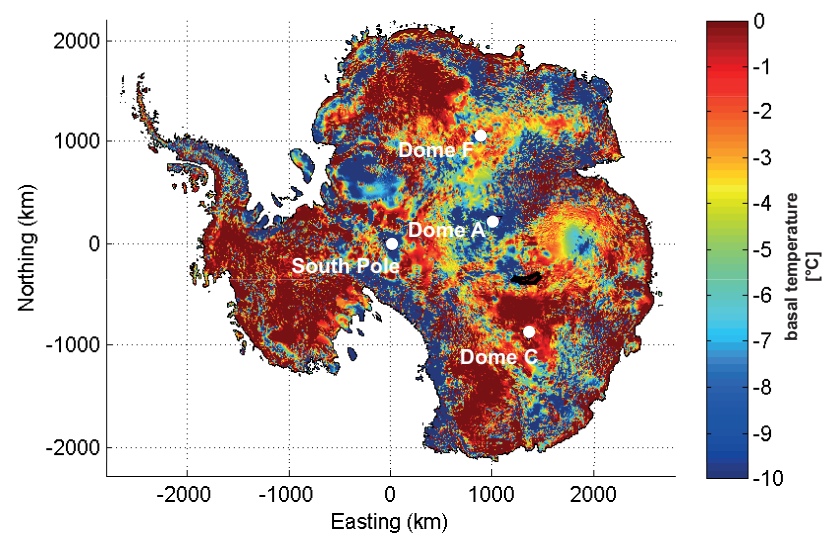

Fig. 9. Basal temperature as derived in the model study by van Liefferinge and Pattyn (2013).

because of the severe lack of information on bedrock geology and heat production by radio decay in this region. Local variations in heat flow are expected to be chiefly from varying concentrations of upper-crustal uranium and thorium, which tend to be enriched in granitic rocks (Neumann et al., 2000). High spatial heterogeneity of heat flow in analogous geological settings in Australia (Neumann et al., 2000) sound a warning note that extrapolation of heat flow in East Antarctica may be too simple and reconnaissance measurements of actual local heat flow are required for the purposes of finding old ice (see below).

As already indicated by the BEDMAP2 ice thickness reconstruction, most of the high plateau regions reach the pressure melting point at the base due to the high ice thickness. The Dome A area is located on top of the Gamburtsev Mountains, and thus shows a rather low ice thickness, and sticks out as an area with frozen bedrock conditions. However, detailed ice radar measurements show that even there deep trenches exist, where bottom melting occurs (Bell et al., 2011). The radar measurements suggest that this water is refreezing downstream, with potential refrozen ice masses reaching up or beyond the neighboring peaks in bedrock topography. Also in the Dome $\mathrm{C}$ area and even more pronounced in the Dome F area, locations (over subglacial mountain tops) exist, where the basal temperature is below the pressure melting point.

\section{Future reconnaissance studies}

As outlined above the search for an Oldest-Ice site is already constrained by the glaciological boundary conditions. The available data and model results allow us to focus the search for such a site to areas close to current dome and potentially saddle or ridge positions, which must combine low accumulation rates and relatively low ice thickness but at the same time smooth bedrock conditions and very low horizontal flow velocities. Alternatively, coastal sites or blue ice zones may provide old ice, but the chance for folding in this kind of ice is even higher and an undisturbed stratigraphy and the ability to accurately date the old ice is a prerequisite to gain the climatic information sought from an Oldest-Ice ice core, as described in the introduction and in Jouzel and MassonDelmotte (2010).

Despite these overall regional constraints, no specific ice core site within these regions can be identified yet based on the data available to date, where we could claim with sufficient certainty that $1.5 \mathrm{Myr}$ old ice should be available. Moreover, drilling of two or even three Oldest-Ice ice cores from different regions may be necessary to prove the integrity of the record in the bottommost ice. The high logistics costs for such an Oldest-Ice project make detailed reconnaissance programs a must. For the future the following approaches have to be followed and their results jointly evaluated:

1. High resolution 3-D radar reconstruction around Dome A, Dome F and Dome C (and selected saddle and ridge position) in regions with ice thicknesses around $2500 \mathrm{~m}$ and areas located leeward of the dome with respect to the main wind direction should be a special focus. These radar studies should comprise both the shallow snow stratigraphy to allow the reconstruction of irregularities in the accumulation rate distribution as well as deep penetrating ice radar to reconstruct the bedrock topography in high-resolution and to get first information on the depth of isochrones and the integrity of the internal layering of the ice. The identification of anomalies in radar isochrones around dome positions (so-called Raymond bumps, Raymond, 1983) will also help to assess, whether the dome position, and thus the depth/age relationship, was stable over time and to pick the location where the oldest ice at the bottom can be expected (Martín and Gudmundsson, 2012). Advanced radar processing using phasecoherent radar (NEEM community members, 2013) is especially important to image near-bed stratigraphy and to verify that it is unfolded and to identify isochrone depressions due to bottom melting.

2. Such high-resolution radar data sets are a prerequisite for 3-D modeling of ice flow in these regions. The latter is essential to constrain the horizontal flow the ice experiences as well as the chance of bottom melting along the flow line upstream of a potential drill site. As the horizontal flow is required to be small, we focus our search to areas in the vicinity of current dome and saddle positions (distance $<100 \mathrm{~km}$ ). Note that changes in ice sheet topography with time have to be considered, that may allow changes in the dome or ridge position and flow direction at the potential drill site. 
3. Combined with the radar studies, intermediate and shallow ice coring should be performed. Shallow (10$100 \mathrm{~m}$ ) ice cores will provide independent age control for the firn radar measurements and, thus, a constraint on the accumulation rate distribution. Moreover, shallow ice cores will provide important information on the spatio-temporal deposition regime of stable water isotopes and chemical aerosol components to be measured in the Oldest-Ice ice core. Intermediate (500$1000 \mathrm{~m}$ ) coring is not so much required to get core material and ice core proxy information, but rapid drilling is needed to measure the temperature profile in the ice and to extrapolate to the bottom temperature. In central East Antarctica, where snow accumulation and thus vertical ice velocities are very low, $500-1000 \mathrm{~m}$ deep bore holes are enough to get a reliable estimate for the bottom temperature, which allows one to exclude bottom melting at the site. Since core extraction is not absolutely necessary for all the intermediate ice cores, fast drilling techniques can be employed. A robust bottom temperature estimate also requires precise estimates of the surface temperature and accumulation rate together with precise borehole temperature measurements.

4. None of the reconnaissance studies above can guarantee $1.5 \mathrm{Myr}$ old ice at the bottom of the ice sheet and only ice coring will deliver the truth. Accordingly, after establishing the bottom temperature and ice thickness at a site, datable samples and proxy information should be retrieved in a fast and logistically efficient way. However, traditional core retrieving techniques are rather slow and require typically three field seasons to drill a $2400 \mathrm{~m}$ deep core. Moreover, such drilling always implies a large field party and high logistic costs, especially in the interior of the East Antarctic ice sheet. Accordingly, rapid access drilling techniques, which allow rapid ice penetration but only limited ice sampling, are strongly advised before a full deep ice core project is started. A minimum requirement of any of those techniques is that they reach the bedrock within less than one field season and deliver information that provides an age estimate of the bottom ice. Currently various such approaches are being developed, which differ in the information gained as well as their logistical demands. These include: (i) employing a heavy movable drill rig (RAID, US Ice Drilling Program) mounted on a vehicle for destructive drilling using rock drilling techniques, interspersed by sampling at selected depths; (ii) a combined melt/mechanical destruction drilling method (SUBGLACIOR, LGGE) using a winched drill instrument, which also carries laser spectroscopic devices on board (Chappellaz et al., 2012). The latter will allow measuring stable water isotopes and methane concentration on board and

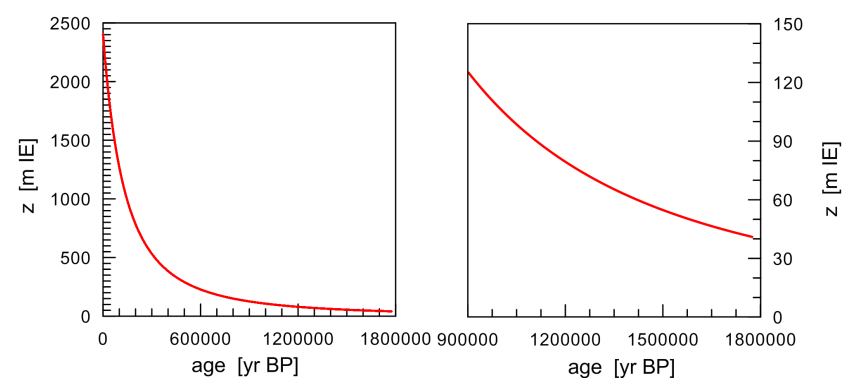

Fig. 10. Age scale of an optimum Oldest-Ice drill site as derived from the simple 1-D model for a geothermal heat flux of $55 \mathrm{~mW} \mathrm{~m}^{-2}$ and a mean surface temperature of $213 \mathrm{~K}$ similar to the the ones at Dome C. For the ice thickness a value of $H=2400 \mathrm{~m}$ and for the mean accumulation rate $A=0.018 \mathrm{~m} \mathrm{IE} \mathrm{yr}^{-1}$ was chosen. The left plot represents the full age scale, the right plot an enlargement of the bottom $150 \mathrm{~m}$.

will bring no samples to the surface; (iii) a minimum diameter coiled tubing technique (RADIX, University of Bern), where the drill chips will be used to date ice samples and special miniature borehole logging tools (such as dust scattering or borehole conductivity devices) can be deployed after drilling; or (iv) a lightweight enclosed auger based drilling system (British Antarctic Survey) designed for rapid deployment by Twin Otter aircraft, capable of reaching $600 \mathrm{~m}$ in a dry borehole in under seven days with the ability to recover ice chips continuously and to provide a borehole for temperature measurements and estimating the local geothermal heat flux.

All these techniques differ substantially in the amount of information they deliver, drill speed and their logistical demands. Especially, the use of drill fluid to equilibrate the hydrostatic pressure in the borehole becomes an issue, since the drill fuel consumption increases with the radius squared of the bore hole. For example a borehole of only $2 \mathrm{~cm}$ requires only about $700 \mathrm{~kg}$ of drill liquid for a $2400 \mathrm{~m}$ deep hole (which can be provided by a small aircraft), while a typical 3 inch $(7.6 \mathrm{~cm})$ hole requires about $9000 \mathrm{~kg}$.

5. A 1.5 million yr old ice core sets new standards for ice core and borehole measurements both in precision, spatial resolution of proxy parameters as well as robustness of the results. Moreover, new dating tools have to be deployed to provide a reliable age scale for such a core. Figure 10 shows our best guess age model and temperature profile for an Oldest-Ice ice coring site with $A=0.018 \mathrm{~m} \mathrm{IE} \mathrm{yr}^{-1}, Q_{\mathrm{G}}=55 \mathrm{~mW} \mathrm{~m}^{-2}$ and $H=2400 \mathrm{~m}$. As can be seen from Fig. 10 the time interval between 800000 and $1500000 \mathrm{yr}$ BP is concentrated in a depth interval of only $70-80 \mathrm{mIE}$. A typical $40000 \mathrm{yr}$ glacial cycle expected for the time period between 1.2-1.5 Myr BP is compressed to less 
than $3 \mathrm{~m}$ and a typical glacial-interglacial transition of $10000 \mathrm{yr}$ length to less than $0.7 \mathrm{~m}$. To obtain a sufficient resolution new continuous flow analysis methods for stable water isotopes, aerosol chemical compounds as well as gases have to be used, which have been recently developed (Kaufmann et al., 2008; Rhodes et al., 2013; Stowasser et al., 2012; Gkinis et al., 2011). However, even if a nominal resolution of $1 \mathrm{~cm}$ can be achieved using these methods, the original signal may be strongly altered or completely lost due to diffusion. For $\mathrm{CO}_{2}$, Bereiter et al. (2013) have shown that glacial-interglacial $\mathrm{CO}_{2}$ changes are only very slightly affected. The same holds true for other greenhouse gases. Accordingly, one of the most important objectives of an Oldest-Ice ice core (reconstructing greenhouse gas changes over the last $1.5 \mathrm{Myr}$ ) should be possible to achieve. However, studies on the diffusion of stable water isotopes on the MIS19 record in the EDC ice core (Pol et al., 2010) revealed an unexpectedly large diffusion length of about $40 \mathrm{~cm}$ at an age of about $780000 \mathrm{yr}$ BP. Assuming the same temperature in the deep ice of the Oldest-Ice site as in the EDC bottom part, this implies that the diffusion length for 1.5 million yr old ice may be as large as $55 \mathrm{~cm}$ (diffusion length is proportional to the square root of $t$ ) and, thus, oscillations of a period of $10000 \mathrm{yr}$ would be entirely lost in the bottom ice and a 40,000 yr glacial-interglacial cycle should be severely damped. Accordingly, other paleo-thermometers, such as the noble gas ratios reflecting global mean ocean temperature (Headly and Severinghaus, 2007), as well as local temperature reconstructions using nitrogen and noble gas isotopes recording the temperature dependent change in the firn column (Kobashi et al., 2011; Caillon et al., 2003) have to be further explored. Also ionic compounds may be subject to diffusional smoothing, while particulate mineral dust should not be impaired by this effect. Accordingly, high-resolution particulate dust records derived from the ice core material as well as from borehole backscattering analysis will become a major objective.

6. Finally, age control becomes a crucial issue. Flow models respond extremely sensitive in the bottom part to wrong input data and require age markers or orbital tuning to be constrained. This could be accomplished by using the orbital signal in the $\mathrm{O}_{2} / \mathrm{N}_{2}$ ratio (Kawamura et al., 2007; Landais et al., 2012) or in $\delta^{18} \mathrm{O}_{2}$ of atmospheric molecular oxygen (Dreyfus et al., 2007). A recent gas diffusion model study (Bereiter et al., 2013) shows that $\mathrm{O}_{2} / \mathrm{N}_{2}$ may be strongly damped by permeation of these gases in the deep ice. These results are still preliminary due to the insufficient knowledge of the permeation constants of gases in clathrate ice. In the worst case scenario (using the

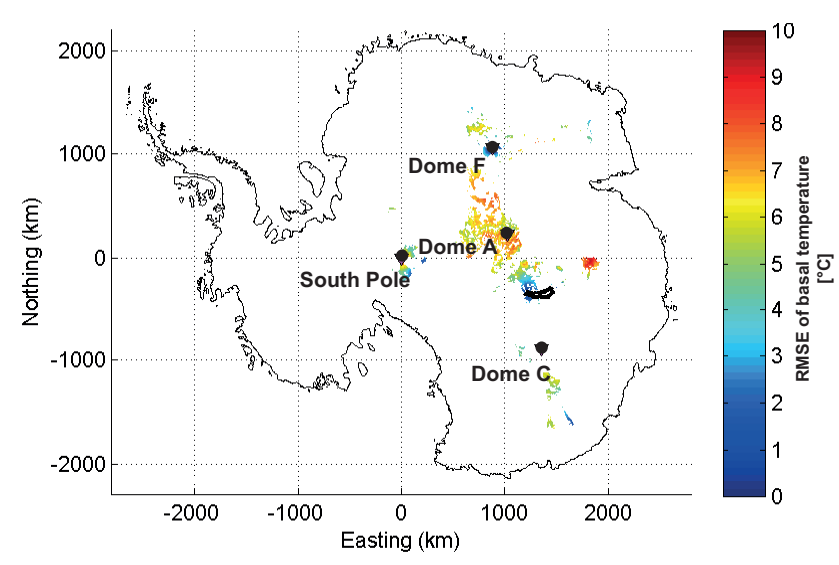

Fig. 11. Potential Oldest-Ice study areas, where horizontal flow is smaller than $2 \mathrm{~m} \mathrm{yr}^{-1}$, mean ice thickness larger than $2000 \mathrm{~m}$ and the bottom temperature below $-5^{\circ} \mathrm{C}$. The color bar indicates the root mean square error of the basal temperature derived from a mode ensemble (van Liefferinge and Pattyn, 2013).

fastest permeation constants available in the literature) the $\mathrm{O}_{2} / \mathrm{N}_{2}$ signal may be entirely lost and could not be used for unambiguous orbital tuning of an OldestIce ice core (Bereiter et al., 2013). Accordingly, radiometric chronological constraints become even more important. Only recently, the increase of ${ }^{40} \mathrm{Ar}$ in the atmosphere, which is produced during ${ }^{40} \mathrm{~K}$ decay in the lithosphere has been employed for dating (Bender et al., 2008). The error of this rather straightforward method is still quite large, but provides a model independent constraint of the age of core material. Also $\mathrm{U} / \mathrm{Th}$ dating has been developed for ice cores and applied to the EDC ice core. This provided accurate ages, however, the error is on the order of $25 \%$ for $800000 \mathrm{yr}$ old ice and becomes substantially larger for 1.5 million yr (Aciego et al., 2011). Absolute age markers are also provided by maxima in the ${ }^{10} \mathrm{Be}$ deposition flux caused by anomalous ${ }^{10} \mathrm{Be}$ production rates during geomagnetic anomalies. For example the oldest such event, currently recorded in the EDC ice core, is the Brunhes-Matuyama geomagnetic reversal 780000 yr ago (Raisbeck et al., 2006a). Other methods such as ${ }^{10} \mathrm{Be} /{ }^{36} \mathrm{Cl}$, amino acid racemization or DNA dating (Willerslev et al., 2007) are explored and may provide additional age constraints for such old ice. To obtain the best age information possible all the dating methods mentioned above should be used in parallel.

\section{Conclusions}

Based on simple 1-D ice and heat flow modeling, in combination with a wide range of geophysical, glaciological and climatological data available to date we conclude that stratigraphically undisturbed ice of an age of 1.5 million yr should 
still exist at the bottom of the East Antarctic ice sheet. In contrast to sites of previous ice cores, where large ice thickness was preferred to obtain higher resolution ice core records from previous glacial cycles, our results show that sites with bottom melting due to too large ice thickness have to be strictly avoided, if $1.5 \mathrm{Myr}$ old ice is to be retrieved. At the same time the ice may not be too thin to find old ice sufficiently above bedrock. These two competing criteria require putting the utmost care and effort into the site selection in order to be able to fulfill the goal of finding undisturbed ice of 1.5 million yr of age. Accordingly, we recommend an OldestIce drill site, where ice thickness for the geothermal heat flux regime encountered at Dome $\mathrm{C}$ is not larger than $2500 \mathrm{~m}$ IE. Our study shows that even with these boundary conditions 1.5 million yr old ice will only be located within the bottommost $100 \mathrm{~m}$. Accordingly, stringent age control and potentially replication of the record will be necessary to prove the integrity of the record. Alternatively, lower geothermal heat fluxes than at Dome $\mathrm{C}$ allow for higher ice thickness and would alleviate the problem of flow disturbances at the bottom. Accordingly, finding lower geothermal heat fluxes as currently encountered at Dome $\mathrm{C}$ would be a highly desirable target and could be accomplished via a campaign of rapid intermediate-depth borehole based measurements of basal heat flow.

At the same time, horizontal ice flow should be avoided as much as possible, as ice transported over long distances in the bottom hundred meters of the ice is prone to flow disturbances. Several ice cores prove that the bottom section affected by flow disturbances is significantly larger for such sites. Accordingly, only drill sites close to the current dome or saddle positions of the East Antarctic ice sheet appear to be recommended for a future Oldest-Ice coring site (as illustrated in Fig. 11 taken from van Liefferinge and Pattyn, 2013).

Despite this focus on few well defined areas, however, an ultimate site selection would be premature and requires further detailed reconnaissance in the field including highresolution radar in concert with much more refined 3dimensional ice and heat flow modeling studies than presented in this paper. Moreover, exploration of the bottom age and temperature using rapid drilling techniques become crucial issues. If these studies are tackled in a concerted effort in the coming years, a site selection and start of an OldestIce deep ice core drilling could still commence within this decade.

Acknowledgements. This work is an outgrowth of the efforts of IPICS (International Partnerships in Ice Core Sciences; http://www.pages-igbp.org/ipics/), which is affiliated to the IGBP project PAGES (Past Global Changes), SCAR (Scientific Committee on Antarctic Research) and IACS (International Association of Cryospheric Sciences). IPICS has received substantial support from NSF (US National Science Foundation) and EPB (European Polar Board). This paper has been initiated during an Oldest-Ice workshop in October 2012, which was financially supported through the EPICA (European Project for Ice Coring in Antarctica) Descartes Prize for Transnational Collaboration 2007. H. Fischer thanks Laura Antón for rediscovering important scientific material, which got lost at a late stage of this paper.

Edited by: C. Barbante

\section{References}

Abe-Ouchi, A., Saito, F., Kawamura, K., Raymo, M. E., Okuno, J., Takahashi, K., and Blatter, H.: Insolation-driven 100,000-year glacial cycles and hysteresis of ice-sheet volume, Nature, 500, 190-193, doi:10.1038/nature12374, 2013.

Aciego, S., Bourdon, B., Schwander, J., Baur, H., and Forieri, A.: Toward a radiometric ice clock: uranium ages of the Dome C ice core, Quaternary Sci. Rev., 30, 2389-2397, doi:10.1016/j.quascirev.2011.06.008, 2011.

Arthern, R. and Gudmundsson, H.: Initialization of ice-sheet forecasts viewed as an inverse Robin problem, J. Glaciol., 56, 527533, 2010.

Arthern, R. J., Winebrenner, D. P., and Vaughan, D. G.: Antarctic snow accumulation mapped using polarization of $4.3-\mathrm{cm}$ wavelength microwave emission, J. Geophys. Res., 111, D06107, doi:10.1029/2004JD005667, 2006.

Bell, R. E., Ferraccioli, F., Creyts, T. T., Braaten, D., Corr, H., Das, I., Damaske, D., Frearson, N., Jordan, T., Rose, K., Studinger, M., and Wolovick, M.: Widespread persistent thickening of the East Antarctic Ice Sheet by freezing from the base, Science, 331, 1592-1595, doi:10.1126/science.1200109, 2011.

Bender, M. L., Barnett, B., Dreyfus, G., Jouzel, J., and Porcelli, D.: The contemporary degassing rate of 40Ar from the solid Earth, Proceed. Natl. Aca. Sci., 105, 8232-8237, 2008.

Bereiter, B., Fischer, H., Schwander, J., and Stocker, T. F.: Diffusive equilibration of $\mathrm{N}_{2}, \mathrm{O}_{2}$ and $\mathrm{CO}_{2}$ mixing ratios in a 1.5 million years old ice core, The Cryosphere Discuss., 7, 2029-2060, doi:10.5194/tcd-7-2029-2013, 2013.

Caillon, N., Severinghaus, J. P., Jouzel, J., Barnola, J.-M., Kang, J., and Lipenkov, V. Y.: Timing of atmospheric $\mathrm{CO}_{2}$ and Antarctic temperature changes across Termination III, Science, 299, 17281731, 2003.

Chappellaz, J., Alemany, O., Romanini, D., and Kerstel, E.: The IPICS “oldest ice" challenge: a new technology to qualify potential sites, Ice and Snow, 5, 57-64, 2012.

Das, I., Bell, R. E., Scambos, T. E., Wolovick, M., Creyts, T. T., Studinger, M., Frearson, N., Nicolas, J. P., Lenaerts, J. T. M., and van den Broeke, M. R.: Influence of persistent wind scour on the surface mass balance of Antarctica, Nat. Geosci., 6, 367-371, doi:10.1038/NGEO1766, 2013.

Dreyfus, G. B., Parrenin, F., Lemieux-Dudon, B., Durand, G., Masson-Delmotte, V., Jouzel, J., Barnola, J.-M., Panno, L., Spahni, R., Tisserand, A., Siegenthaler, U., and Leuenberger, M.: Anomalous flow below $2700 \mathrm{~m}$ in the EPICA Dome C ice core detected using $\delta^{18} \mathrm{O}$ of atmospheric oxygen measurements, Clim. Past, 3, 341-353, doi:10.5194/cp-3-341-2007, 2007.

Eisen, O., Rack, W., Nixdorf, U., and Wilhelms, F.: Characteristics of accumulation around the EPICA deep-drilling site in Dronning Maud Land, Antarctica, Ann. Glaciol., 41, 41-46, 2005. 
Eisen, O., Frezzotti, M., Genthon, C., Isaksson, E., Magand, O., van den Broeke, M. R., Dixon, D. A., Ekaykin, A., Holmlund, P., Kameda, T., Karlof, L., Kaspari, S., Lipenkov, V. Y., Oerter, H., Takahashi, S., and Vaughan, D. G.: Ground-based measurements of spatial and temporal variability of snow accumulation in East Antarctica, Rev. Geophys., 46, RG2001, doi:10.1029/2006RG000218, 2008.

Elderfield, H., Ferretti, P., Greaves, M., Crowhurst, S., McCave, I. N., Hodell, D., and Piotrowski, A. M.: Evolution of ocean temperature and ice volume through the Mid-Pleistocene climate transition, Science, 337, 704-709, doi:10.1126/science.1221294, 2012.

EPICA community members: Eight glacial cycles from an Antarctic ice core, Nature, 429, 623-628, 2004.

EPICA community members: One-to-one coupling of glacial climate variability in Greenland and Antarctica, Nature, 444, 195198, 2006.

Fretwell, P., Pritchard, H. D., Vaughan, D. G., Bamber, J. L., Barrand, N. E., Bell, R., Bianchi, C., Bingham, R. G., Blankenship, D. D., Casassa, G., Catania, G., Callens, D., Conway, H., Cook, A. J., Corr, H. F. J., Damaske, D., Damm, V., Ferraccioli, F., Forsberg, R., Fujita, S., Gim, Y., Gogineni, P., Griggs, J. A., Hindmarsh, R. C. A., Holmlund, P., Holt, J. W., Jacobel, R. W., Jenkins, A., Jokat, W., Jordan, T., King, E. C., Kohler, J., Krabill, W., Riger-Kusk, M., Langley, K. A., Leitchenkov, G., Leuschen, C., Luyendyk, B. P., Matsuoka, K., Mouginot, J., Nitsche, F. O., Nogi, Y., Nost, O. A., Popov, S. V., Rignot, E., Rippin, D. M., Rivera, A., Roberts, J., Ross, N., Siegert, M. J., Smith, A. M., Steinhage, D., Studinger, M., Sun, B., Tinto, B. K., Welch, B. C., Wilson, D., Young, D. A., Xiangbin, C., and Zirizzotti, A.: Bedmap2: improved ice bed, surface and thickness datasets for Antarctica, The Cryosphere, 7, 375-393, doi:10.5194/tc-7-3752013, 2013.

Fujita, S., Holmlund, P., Andersson, I., Brown, I., Enomoto, H., Fujii, Y., Fujita, K., Fukui, K., Furukawa, T., Hansson, M., Hara, K., Hoshina, Y., Igarashi, M., Iizuka, Y., Imura, S., Ingvander, S., Karlin, T., Motoyama, H., Nakazawa, F., Oerter, H., Sjöberg, L. E., Sugiyama, S., Surdyk, S., Ström, J., Uemura, R., and Wilhelms, F.: Spatial and temporal variability of snow accumulation rate on the East Antarctic ice divide between Dome Fuji and EPICA DML, The Cryosphere, 5, 1057-1081, doi:10.5194/tc-51057-2011, 2011.

Fujita, S., Holmlund, P., Matsuoka, K., Enomoto, H., Fukui, K., Nakazawa, F., Sugiyama, S., and Surdyk, S.: Radar diagnosis of the subglacial conditions in Dronning Maud Land, East Antarctica, The Cryosphere, 6, 1203-1219, doi:10.5194/tc-61203-2012, 2012.

Gkinis, V., Popp, T. J., Blunier, T., Bigler, M., Schüpbach, S., Kettner, E., and Johnsen, S. J.: Water isotopic ratios from a continuously melted ice core sample, Atmos. Meas. Tech., 4, 25312542, doi:10.5194/amt-4-2531-2011, 2011.

Grootes, P. M., Stuiver, M., White, J. W. C., Johnsen, S., and Jouzel, J.: Comparison of oxygen isotope records from the GISP2 and GRIP Greenland ice cores, Nature, 366, 552-554, 1993.

Headly, M. A. and Severinghaus, J. P.: A method to measure Kr/N2 ratios in air bubbles trapped in ice cores and its application in reconstructing past mean ocean temperature, J. Geophys. Res., 112, D19105, doi:10.1029/2006JD008317, 2007.
Hönisch, B., Hemming, N. G., Archer, D., Siddall, M., and McManus, J.: Atmospheric carbon dioxide concentration across the Mid-Pleistocene Transition, Science, 324, 1551-1554, 2009.

Huybrechts, P.: Sea-level changes at the LGM from ice-dynamic reconstructions of the Greenland and Antarctic ice sheets during the glacial cycles, Quaternary Sci. Rev., 21, 203-231, 2002.

Jouzel, J. and Masson-Delmotte, V.: Deep ice cores: the need for going back in time, Quaternary Sci. Rev., 29, 3683-3689, 10.1016/j.quascirev.2010.10.002, 2010.

Jouzel, J., Masson-Delmotte, V., Cattani, O., Dreyfus, G., Falourd, S., Hoffmann, G., Minster, B., Nouet, J., Barnola, J.-M., Chappellaz, J., Fischer, H., Gallet, J. C., Johnsen, S., Leuenberger, M., Loulergue, L., Lüthi, D., Oerter, H., Parrenin, F., Raisbeck, G., Raynaud, D., Schwander, J., Spahni, R., Souchez, R., Selmo, E., Schilt, A., Steffensen, J. P., Stenni, B., Stauffer, B., Stocker, T. F., Tison, J.-L., Werner, M., and Wolff, E. W.: Orbital and millennial Antarctic climate variability over the last 800,000 years, Science, 317, 793-796, 2007.

Kaufmann, P., Federer, U., Hutterli, M. A., Bigler, M., Schüpbach, S., Ruth, U., Schmitt, J., and Stocker, T. F.: An improved Continuous Flow Analysis (CFA) system for high-resolution field measurements on ice cores, Environ. Sci. Technol., 42, 8044-8050, doi:10.1021/es8007722, 2008.

Kawamura, K., Parrenin, F., Uemura, R., Vimeux, F., Severinghaus, J. P., Hutterli, M. A., Nakazawa, T., Aoki, S., Jouzel, J., Raymo, M. E., Matsumoto, K., Nakata, H., Motoyama, H., Fujita, S., Goto-Azuma, K., Fujii, Y., and Watanabe, O.: Northern Hemisphere forcing of climatic cycles in Antarctica over the past 360,000 years Nature, 448, 912-917, doi:10.1038/nature06015, 2007.

Kobashi, T., Kawamura, K., Severinghaus, J. P., Barnola, J.-M., Nakaegawa, T., Vinther, B. M., Johnsen, S. J., and Box, J. E.: High variability of Greenland surface temperature over the past 4000 years estimated from trapped air in an ice core, Geophys. Res. Lett., 38, L21501, doi:10.1029/2011GL049444, 2011.

Landais, A., Dreyfus, G., Capron, E., Pol, K., Loutre, M. F., Raynaud, D., Lipenkov, V. Y., Arnaud, L., Masson-Delmotte, V., Paillard, D., Jouzel, J., and Leuenberger, M.: Towards orbital dating of the EPICA Dome C ice core using $\delta \mathrm{O}_{2} / \mathrm{N}_{2}$, Clim. Past, 8 , 191-203, doi:10.5194/cp-8-191-2012, 2012.

Lisiecki, L. E. and Raymo, M. E.: A Pliocene-Pleistocene stack of 57 globally distributed benthic $\delta^{18} \mathrm{O}$ records, Paleoceanogr., 20, PA1003, doi:10.1029/2004PA001071, 2005.

Loulergue, L., Schilt, A., Spahni, R., Masson-Delmotte, V., Blunier, T., Lemieux, B., Barnola, J.-M., Raynaud, D., Stocker, T. F., and Chappellaz, J.: Orbital and millennial-scale features of atmospheric $\mathrm{CH}_{4}$ over the past 800,000 years, Nature, 453, 383 386, 2008.

Lüthi, D., Le Floch, M., Bereiter, B., Blunier, T., Barnola, J.-M., Siegenthaler, U., Raynaud, D., Jouzel, J., Fischer, H., Kawamura, K., and Stocker, T. F.: High-resolution carbon dioxide concentration record 650,000-800,000 years before present, Nature, 453, 379-382, doi:10.1038/nature06949, 2008.

Martín, C. and Gudmundsson, G. H.: Effects of nonlinear rheology, temperature and anisotropy on the relationship between age and depth at ice divides, The Cryosphere, 6, 1221-1229, doi:10.5194/tc-6-1221-2012, 2012. 
NEEM community members: Eemian interglacial reconstructed from a Greenland folded ice core, Nature, 493, 489-494, doi:10.1038/nature11789, 2013.

Neumann, N., Sandiford, M., and Foden, J.: Regional geochemistry and continental heat flow: implications for the origin of the South Australian heat flow anomaly, Earth Planet. Sci. Let., 183, 107120, doi:10.1016/S0012-821X(00)00268-5, 2000.

North Greenland Ice Core Project members: High resolution climate record of the Northern Hemisphere reaching into the last interglacial period, Nature, 431, 147-151, 2004.

Pahnke, K. and Zahn, R.: Southern hemisphere water mass conversion linked with North Atlantic climate variability, Science, 307, 1741-1746, 2005.

Parrenin, F., Jouzel, J., Waelbroeck, C., Ritz, C., and Barnola, J.-M.: Dating the Vostok ice core by an inverse method, J. Geophys. Res., 106, 31837-31851, 2001.

Parrenin, F., Barnola, J.-M., Beer, J., Blunier, T., Castellano, E., Chappellaz, J., Dreyfus, G., Fischer, H., Fujita, S., Jouzel, J., Kawamura, K., Lemieux-Dudon, B., Loulergue, L., MassonDelmotte, V., Narcisi, B., Petit, J.-R., Raisbeck, G., Raynaud, D., Ruth, U., Schwander, J., Severi, M., Spahni, R., Steffensen, J. P., Svensson, A., Udisti, R., Waelbroeck, C., and Wolff, E.: The EDC3 chronology for the EPICA Dome C ice core, Clim. Past, 3, 485-497, doi:10.5194/cp-3-485-2007, 2007a.

Parrenin, F., Dreyfus, G., Durand, G., Fujita, S., Gagliardini, O., Gillet, F., Jouzel, J., Kawamura, K., Lhomme, N., MassonDelmotte, V., Ritz, C., Schwander, J., Shoji, H., Uemura, R., Watanabe, O., and Yoshida, N.: 1-D-ice flow modelling at EPICA Dome C and Dome Fuji, East Antarctica, Clim. Past, 3, 243-259, doi:10.5194/cp-3-243-2007, 2007b.

Parrenin, F., Masson-Delmotte, V., Köhler, P., Raynaud, D., Paillard, D., Schwander, J., Barbante, C., Landais, A., Wegner, A., and Jouzel, J.: Synchronous change of atmospheric $\mathrm{CO}_{2}$ and Antarctic temperature during the last deglacial warming, Science, 339, 1060-1063, doi:10.1126/science.1226368, 2013.

Paterson, W. S. B.: The physics of glaciers, 3rd Edn., Elsevier Science Ltd., Oxford, 480 pp., 1994.

Pattyn, F.: Antarctic subglacial conditions inferred from a hybrid ice sheet/ice stream model, Earth. Planet. Sci. Let., 295, 451-461, doi:10.1016/j.eps1.2010.04.025, 2010.

Pedro, J. B., Rasmussen, S. O., and van Ommen, T. D.: Tightened constraints on the time-lag between Antarctic temperature and $\mathrm{CO}_{2}$ during the last deglaciation, Clim. Past, 8, 1213-1221, doi:10.5194/cp-8-1213-2012, 2012.

Petit, J. R., Jouzel, J., Raynaud, D., Barkov, N. I., Barnola, J.-M., Basile, I., Bender, M., Chappellaz, J., Davis, M., Delaygue, G., Delmotte, M., Kotlyakov, V. M., Legrand, M., Lipenkov, V. Y., Lorius, C., Pepin, L., Ritz, C., Saltzman, E., and Stievenard, M.: Climate and atmospheric history of the past 420,000 years from the Vostok ice core, Antarctica, Nature, 399, 429-436, 1999.

Pol, K., Masson-Delmotte, V., Johnsen, S., Bigler, M., Cattani, O., Durand, G., Falourd, S., Jouzel, J., Minster, B., Parrenin, F., Ritz, C., Steen-Larsen, H. C., and Stenni, B.: New MIS 19 EPICA Dome $\mathrm{C}$ high resolution deuterium data: Hints for a problematic preservation of climate variability at sub-millennial scale in the "oldest ice", Earth Planet. Sci. Let., 298, 95-103, doi:10.1016/j.epsl.2010.07.030, 2010.

Pollard, D. and DeConto, R. M.: Hysteresis in Cenozoic Antarctic ice-sheet variations, Global Planet. Change, 45, 9-21, 2005.
Raisbeck, G., Yiou, F., Cattani, O., and Jouzel, J.: 10Be evidence for the Matuyama-Brunhes geomagnetic reversal in the EPICA Dome C ice core, Nature, 444, 82-84, 2006 a.

Raisbeck, G. M., Yiou, F., Cattani, O., and Jouzel, J.: 10Be evidence for the Matuyama-Brunhes geomagnetic reversal in the EPICA Dome C ice core, Nature, 444, 82-84, 10.1038/nature05266, $2006 b$.

Raymo, M. E., Lisiecki, L. E., and Nisancioglu, K. H.: PlioPleistocene ice volume, Antarctic climate, and the global $\delta^{18} \mathrm{O}$ record, Science, 313, 492-495, 2006.

Raymond, C. F.: Deformation in the vicinity of ice divides, J. Glaciol., 29, 357-373, 1983.

Raynaud, D., Barnola, J.-M., Souchez, R., Lorrain, R., Petit, J.-R., Duval, P., and Lipenkov, V. Y.: The record for marine isotopic stage 11, Nature, 436, 39-40, 2005.

Rhodes, R. H., Fain, X., Stowasser, C., Blunier, T., Chappellaz, J., McConnell, J. R., Romanini, D., Mitchell, L. E., and Brook, E. J.: Continuous methane measurements from a late Holocene Greenland ice core: Atmospheric and in-situ signals, Earth Planet. Sci. Let., 368, 9-19, doi:10.1016/j.eps1.2013.02.034, 2013.

Ritz, C.: Un modele thermo-mechnique d'evolution pour le bassin glaciaire Antarctique Vostok - Glacier Byrd: Sensibilite aux valeurs des parmetres mal connus, $\mathrm{PhD}$, Laboratoire de Glaciologie et Géophysique de l'Environment, Université Joseph Fourier, Grenoble, Grenoble, 1992.

Ritz, C., Rommelaere, V., and Dumas, C.: Modeling the evolution of Antarctic ice sheet over the last 420,000 years: Implications for altitude changes in the Vostok region, J. Geophys. Res., 106, 31943-31964, 2001.

Ruth, U., Barnola, J.-M., Beer, J., Bigler, M., Blunier, T., Castellano, E., Fischer, H., Fundel, F., Huybrechts, P., Kaufmann, P., Kipfstuhl, S., Lambrecht, A., Morganti, A., Oerter, H., Parrenin, F., Rybak, O., Severi, M., Udisti, R., Wilhelms, F., and Wolff, E.: "EDML1": a chronology for the EPICA deep ice core from Dronning Maud Land, Antarctica, over the last 150000 years, Clim. Past, 3, 475-484, doi:10.5194/cp-3-475-2007, 2007.

Scambos, T. A., Frezzotti, M., Haran, T., Bohlander, J., Lenaerts, J. T. M., van den Broeke, M. R., Jezek, K., Long, D., Urbini, S., Farness, K., Neumann, T., Albert, M., and Winther, J.-G.: Extent of low-accumulation "wind glaze" areas on the East Antarctic plateau: implications for continental ice mass balance, J. Glaciol., 58, 633-647, 2012.

Severinghaus, J. P., Albert, M. R., Courville, Z. R., Fahnestock, M. A., Kawamura, K., Montzka, S. A., Muhle, J., Scambos, T. A., Shields, E., Shuman, C. H., Suwa, M., Tans, P., and Weiss, R. F.: Deep air convection in the firn at a zero-accumulation site, central Antarctica, Earth Planet. Sci. Let., 293, 359-367, doi:10.1016/j.eps1.2010.03.003, 2010.

Shakun, J. D., Clark, P. U., He, F., Marcott, S. A., Mix, A. C., Liu, Z., Otto-Bliesner, B., Schmittner, A., and Bard, E.: Global warming preceded by increasing carbon dioxide concentrations during the last deglaciation, Nat. Geosci., 484, 49-055, doi:10.1038/nature10915, 2012.

Singer, B., and Brown, L. L.: The Santa Rosa Event: ${ }^{40} \mathrm{Ar} /{ }^{39} \mathrm{Ar}$ and paleomagnetic results from the Valles rhyolite near Jaramillo Creek, Jemez Mountains, New Mexico, Earth Planet. Sci. Let., 197, 51-64, 2002.

Stowasser, C., Buizert, C., Gkinis, V., Chappellaz, J., Schüpbach, S., Bigler, M., Fa in, X., Sperlich, P., Baumgartner, M., Schilt, 
A., and Blunier, T.: Continuous measurements of methane mixing ratios from ice cores, Atmos. Meas. Tech., 5, 999-1013, doi:10.5194/amt-5-999-2012, 2012.

Van Liefferinge, B. and Pattyn, F.: Using ice-flow models to evaluate potential sites of million year-old ice in Antarctica, Clim. Past Discuss., 9, 2859-2887, doi:10.5194/cpd-9-2859-2013, 2013.

Vittuari, L., Vincent, C., Frezzotti, M., Mancini, F., Gandolfi, S., Bitelli, G., and Capra, A.: Space geodesy as a tool for measuring ice surface velocity in the Dome $\mathrm{C}$ region and along the ITASE traverse, Ann. Glaciol., 39, 402-408, 2004.

Wang, Y., Cheng, H., Edwards, R. L., Kong, X., Shao, X., Chen, S., Wu, J., Jiang, X., Wang, X., and An, Z.: Millennial- and orbitalscale changes in the East Asian monsoon over the past 224,000 years, Nature, 451, 1090-1093, 10.1038/nature06692, 2008.

Willerslev, E., Cappellini, E., Boomsma, W., Nielsen, R., Hebsgaard, M. B., Brand, T. B., Hofreiter, M., Bunce, M., Poinar, H. N., Dahl-Jensen, D., Johnsen, S., Steffensen, J. P., Bennike, O., Schwenninger, J.-L., Nathan, R., Armitage, S., de Hoog, C.-J., Alfimov, V., Christl., M., Beer, J., Muscheler, R., Barker, J., Sharp, M., Penkman, K. E. H., Haile, J., Taberlet, P., Thomas, M., Gilbert, P., Casoli, A., Campani, E., and Collins, M. J.: Ancient biomolecules from deep ice cores reveal a forested Southern Greenland, Science, 317, 111-114, doi:10.1126/science.1141758, 2007.
Wolff, E. W., Fischer, H., Fundel, F., Ruth, U., Twarloh, B., Littot, G. C., Mulvaney, R., de Angelis, M., Boutron, C. F., Hansson, M., Jonsell, U., Hutterli, M., Bigler, M., Lambert, F., Kaufmann, P., Röthlisberger, R., Steffensen, J. P., Siggaard-Andersen, M.-L., Udisti, R., Becagli, S., Castellano, E., Severi, M., Wagenbach, D., Barbante, C., Gabrielli, P., and Gaspari, V.: Southern Ocean sea ice, DMS production and iron flux over the last eight glacial cycles, Nature, 440, 491-496, 2006.

Wolovick, M., Bell, R. E., Buck, W. R., and Creyts, T. T.: Controls on the geometry of accretion reflectors, Eos, Transactions, American Geophysical Union, Fall 2012 Annual Meeting, San Francisco, CA, Abstracts with programs, 2012.

Zachos, J., Pagani, M., Sloan, L., Thomas, E., and Billups, K.: Trends, rhythms, and aberrations in global climate $65 \mathrm{Ma}$ to present, Science, 292, 686-693, 2001. 